Portland State University

PDXScholar

7-8-1977

\title{
Choice and Success: The Evolution of a Modern Hero
}

Laurence W. Ranstead

Portland State University

Follow this and additional works at: https://pdxscholar.library.pdx.edu/open_access_etds

Part of the Literature in English, British Isles Commons Let us know how access to this document benefits you.

\section{Recommended Citation}

Ranstead, Laurence W., "Choice and Success: The Evolution of a Modern Hero" (1977). Dissertations and Theses. Paper 2575.

https://doi.org/10.15760/etd.2573

This Thesis is brought to you for free and open access. It has been accepted for inclusion in Dissertations and Theses by an authorized administrator of PDXScholar. Please contact us if we can make this document more accessible: pdxscholar@pdx.edu. 
AN ABSTRACT OF THE THESIS OF Laurence W. Ranstead for the Master of Arts in English presented July 8, 1977.

Title: Choice and Success: The Evolution of a Modern Hero. APPROVED BY MEMBERS OF THE THESIS COMMITTEE:
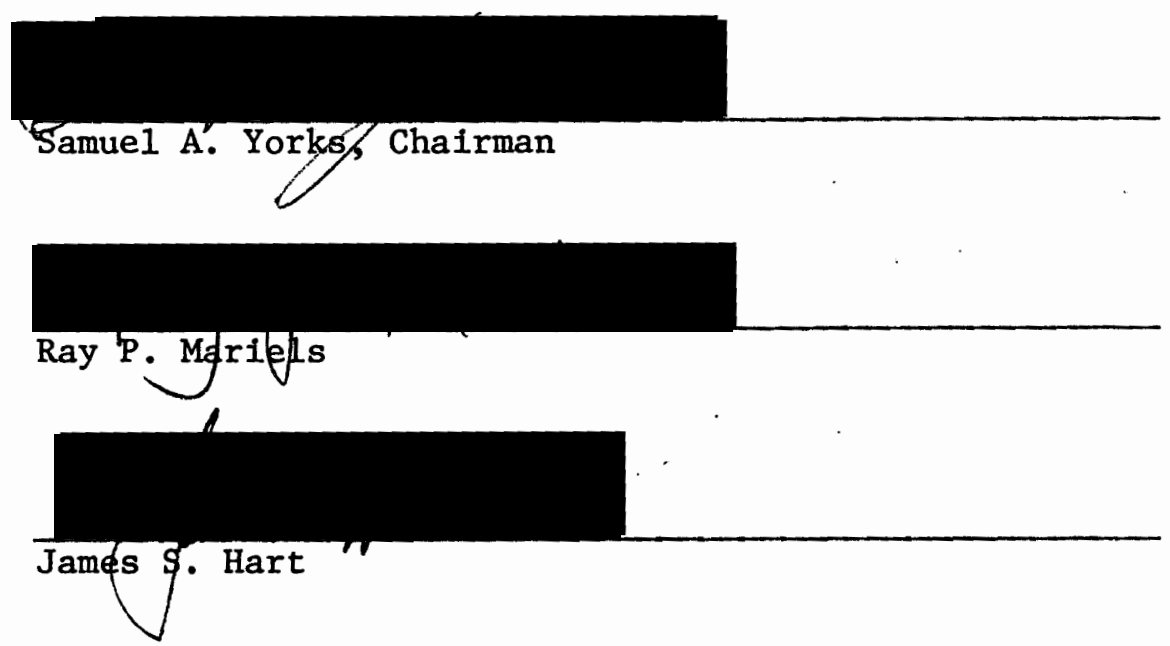

The phenomenon of modern fantasy is the result of a tradition that originated with romance. It is a tradition that has experienced continual redefinement and utilization over the years. This is evidenced by the rediscovery of certain characteristics of the Medieval Romance and the development of others by the Romantics, William Blake, William Wordsworth, and Samuel Taylor Coleridge. These characteristics are Identifiable in the works of such later writers as Charles Dickens, William Morris, H. G. Wells, G. B. Shaw, C. S. Lewis and J. R. R. Tolkien. The concern of these succeeding authors is the same as that of the Romantics, $1 . e .$, the nature and condition of man in modern technological society. The study of the works of these authors reveals two distinct 
approaches to the relationship of man and his society, and these approaches produce two different types of hero.

The traditional hero of romance is what I choose to call the Hero of Success. He is basically an extrovert in the respect that he obtains his values from outside himself, from his society. His success or failure to perform his given task is a measure of the strength or weakness of the values that he subscribes to, and his ability to follow their dictates.

The second type, the Hero of Cholce, is an introvert in that his values are obtained from within himself. In addition, this hero must choose between those values which he finds within himself and those which are available to him from without. The Hero of Choice and his individuality is a more recent development than the Hero of Success, appearing as it does with the beginning of the nineteenth century. Since that time the Hero of Choice has undergone an evolution to full development in works of modern fantasy. 
CHOICE AND SUCCESS: THE EVOLUTION OF

A MODERN HERO

by

LAURENCE W. RANSTEAD

A thesis submitted in partial fulfillment of the requirements for the degree of

\section{MASTER OF ARTS}

in

ENGLISH

Portland State University

1977 
TO THE OFFICE OF GRADUATE STUDIES AND RESEARCH:

The members of the Committee approve the thesis of Laurence W. Ranstead presented July 8, 1977.

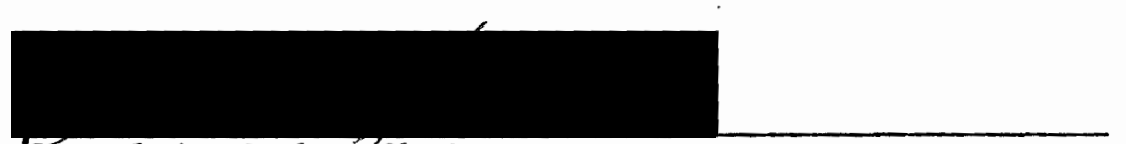

Samue1 A. Yorks Chairman
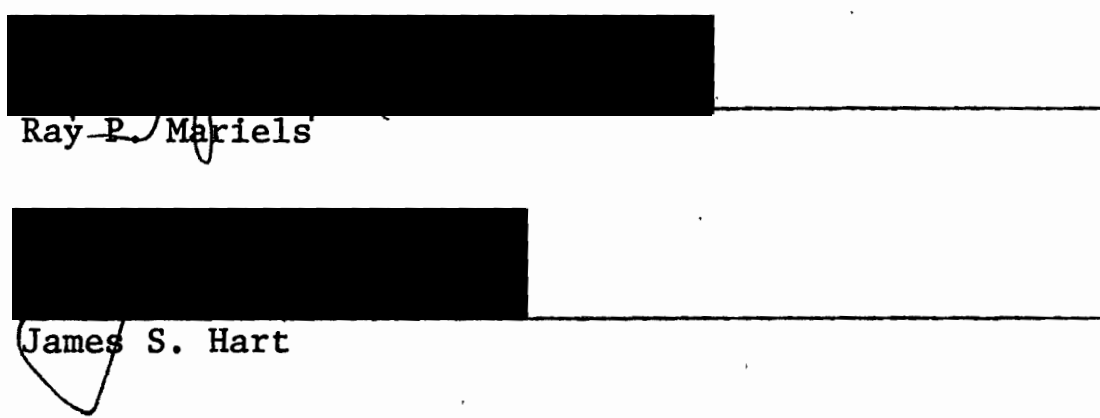

APPROVED:
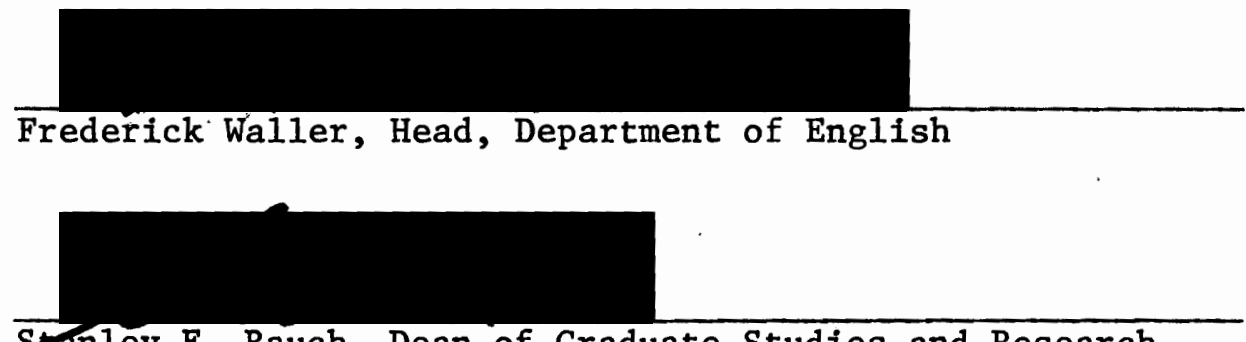

Stanley E. Rauch, Dean of Graduate Studies and Research 


\section{ACKNOWLEDGMENTS}

My thanks to Dr. Samuel A. Yorks for his enthusiasm, patience, and direction without which this project would have floundered. I also wish to thank the members of my committee, James Hart and Ray Mariels whose criticisms were indispensable. 
TABLE OF CONTENTS

PAGE

ACKNOWLEDGMENTS. ................. . iii

CHAPTER

I INTRODUCTION . . . . . . . . . . . . . . 1

II THE HERO OF SUCCESS. . . . . . . . . . . . 12

III THE ROMANTIC LEGACY: THE HERO OF CHOICE . . . . . 25

IV THE VICTORIANS . . . . . . . . . . . 35

V THE TWENTIETH CENTURY. . . . . . . . . . 50

Sherlock Holmes. . . . . . . . . . 50

H. G. Hells. . . . . . . . . . 56

G. B. Shaw .............. 61

VI FANTASY. . . . . . . . . . . . . 71

VII J. R. R. TOLKIEN AND C. S. LEWIS . . . . . . . 80

VIII CONCLUSION . . . . . . . . . . . . . 90

BIBLIOGRAPHY ........................... 93 
CHAPTER 1

\section{INTRODUCTION}

This study began as a result of an interest in works of modern fantasy, and the incomprehensible tendency for those works to be classified with other works that had few, if any features in common. Consequently, I sought to discover the reason for this seemingly arbitrary classification. My first thought was of the romance and its obvious similarities with many so-called fantasies, but that led to nothing. In fact, so similar were those two forms that I was at first unable to clearly distinguish between the two. Only after reading the list of heroes and their characteristics in Northrop Frye's Anatomy of Criticism, did I realize that the difference has something to do with the nature and treatment of the hero. As a result, I began to consider the heroes as they appeared in those works of fantasy and romance, and this yielded positive and workable distinctions. However, I also discovered that the study of these heroes had implications in areas other than just fantasy.

Essentially, there were two different types of heroes that appeared. I have chosen to call these two the heroes of Choice and Success, and both will be dealt with in depth in the chapters which follow. Here It is necessary to explain the manner and meaning of my thoughts concerning them.

First and foremost, the concept of choice, which is the primary characteristic which separates these two types, should be considered. 
I do not mean to imply that this distinction is based merely on the presence or absence of a choice made by a given hero. In at least one sense all heroes could be sald to have a cholce in the matter of their actions. It could be argued that a character such as a Beowulf or a Gawain consciously choose to act as they do, but such an argugenent would ultimately rest upon the assumptions of the reader and the implications of the author, for there is little evidence in the text to support such conclusions. The works which contain this type of hero are not concerned with individual choice as motivation, as much as they are concerned with the actions of the hero and a depiction of a socially acceptable heroic ethic. Consequently, the choice which allows for a distinction between these two hero types can not be assumed or left to implication. Such a distinction is based upon the degree of choice textually attributable to the hero.

Whereas the Hero of Success lacks this degree of cholce, the Hero of Choice does not. Works which contain this second type depict a hero who actively struggles with his conscience before he arrives at his decision to act. He is clearly aware of his own individuality and that as an individual alternative modes of action are available to him. Textually, his consideration of these alternatives is likely to span pages if not complete chapters before a decision may be reached. Once declded the author does not usually allow the reader to forget that such a choice has in fact been made, for continual references are made to this initial choice. The Hero of Choice is free to choose and is not limited in any manner. He may choose to follow the prescriptive dictates of society (the usual case in works other than romance) or he may choose to disregard that charge and act as his own consclence dictates. 
In romance and fantasy, when the hero chooses to disregard the accepted behavior patterns of his society, the result is his alienation from that society. He is labelled a revolutionary opposed to the goals of society or in opposition to the natural order. An alternative view of this apparent rebellious aspect of the hero's character is that he is first the revolutionary and hero second. Such a controversy could easily take on the appearance of the chicken-and-egg argument if it were not for the fact that the view which is unable to separate hero and revolutionary is based upon a definition of behavior which resides not in the individual but in the society. Revolutionary and revolutionist have meaning in the sense that they are social terms applied by society to that individual who acts in the negative. The Hero of Choice would be better described as a rebel, but rebel in the sense of disobedience. For like the child, he seeks only to accomplish a goal not acceptable to his parents. This goal may be ego directed or it may be understood in humanitarian terms as good for all, but the important point to remember is that it is a goal not sanctioned by society. This lack of sanctioned goals and the determination of the Hero of Choice to achieve them, result in the allenation and the persecution he undergoes.

To be a Hero of Success necessitates that the hero have the authoritative approval of the group to which he belongs. As long as he behaves in the manner prescribed by the group he may rightfully expect to succeed. Even should such a hero fail at his task, his failure is laudable simply because he followed and sought the sanctioned goals of his group. This is the case with Beowulf. He was a good king because he did what his group considered a good king should do. When 
he died, his death did not diminish his success as a king. Instead, it is a further example to others. To be a good $\mathrm{king}$, one must be willing to give one's life for the group.

Very little has changed since this Anglo-Saxon group awareness was the norm. The group itself has become larger--the group awareness moving from family to tribe to the elghteenth century concept of society-and the sanctioned behavior and goal of the group have become more complex as society complicated itself, but the Hero of Success has not changed. A Gulliver or a Robinson Crusoe succeed because they behave in precisely the maner 'good' members of the group should. Robinson Crusoe is not the story of an island supporting a shipwrecked man, but of the group exploiting the island. The castaway reacts to nature, not with it. He brings his empire with him and through it dominates and exploits the island.

Jonathan Swift, on the other hand, had something else in mind. Satire requires immersion in the group with an awareness of the conflicts that are inherent to the nature of the group. On the social level, satire stems from the society's need to improve itself. Religious satire is representative of the same need. This need is evidenced by the very nature of satire. It does not strive to burden itself with individuality but deals with groups. Gulliver experiences his adventures moving from one group to the next. This is quite different from social criticism as it appears in the nineteenth century simply by the fact that the social novel at least implies some type of individuality not evidenced in satire.

The more serious case of the revolutionary, a kind of penultimate social critic, also implies individuality. But this may be implied 
only. The revolutionary, like the social critic, may be a reflection of the satirist's immersion in the group. When revolution and social criticism become socially sanctioned solutions to the need for change and improvement (definitely not the case with the divine right of kings) and a hero acts accordingly, he remains the Hero of Success. For once again, his success is culturally determined and approved, and as such his behavior is no different than that of a Beowulf or a Gawain. When the hero of literature is, of necessity, also a revolutionary he loses the freedom to choose to be one. In such cases, revolution becomes an heroic code as deterministic as that of the Anglo-Saxon or the medieval romance. The hero must become the revolutionary, there are no alternatives to be considered and consequently such a hero can not be a Hero of Choice. Byron's Don Juan is this type of revolutionary hero. As social criticism developed in the nineteenth century the hero/revolutionary became as much a norm as any other social critic.

The second matter to be considered here is the division of these heroes into types. Traditionally, the number of heroes recognized in all literature is vast if not infinite. My division of such numbers into only two types may seem an unacceptable simplification, but I think not. The two types, Choice and Success, are meant as the word type applies to archetype. They are two primary divisions which may be made to aid the reader in thinking about heroes. Within each of these divisions there can occur any number of variations, For example, with the Success type, some are heroes without choice as discussed above and as will be seen later, there are those that succeed and those that: fail. Similarly, within the Choice type we may also recognize both the hero who succeeds and the one who fails. Furthermore, I do not find 
that the divisions I am making are inconsistent or contradictory to other defined patterns. Traditionally romantic heroes are said to be "active" and "passive." Both have the capacity of becoming a Hero of Success, and each is capable of becoming a Hero of Choice. More important is the fact that both may be discussed in terms of choice. I have not tried to slight nor supplant those heroes that have been with us for so long, but merely recognize an additional critical approach which may be brought to them. In doing so I have thought of these two types and their variations as one would consider the genealogical tables of two different families or the Linnaean System of kingdom/phylum/class in biology. However, such a systematic mapping is beyond the scope of this thesis. Indeed, to do it at all would take a booklength work or two. Instead, I have limited the scope to a discussion of only these two types using selected examples to explain them. These examples also show the development and utilization of the two heroes over the years.

Development, evolution if you will, brings to light the third point to be made here. I do not find the Hero of Choice prior to the nineteenth century, but that should be amended to read "the fully developed Hero of Choice." Very little happens in this universe overnight, and this is true of literature as well. I'm sure that threads and partial webs of this concept of choice could be traced back through earlier periods. Indeed, the curlous behavior of Ulysses and Achilles is a tantalizing and remarkably early hint at what the concept of choice was later to become. Shakespeare's Hamlet is likeways intriguing for the emphasis upon his vacillation. That such cases exist is undeniable evidence for the fact that individual cholce and responsibility for that choice was long developing. However, to trace such threads is again, 
like the genealogy of heroes, not my intention. Instead, I begin my discussion of the Hero of Choice at a point at which it is fully realized. Prior to this point, he was only in the germinal state.

I attribute the development of the Hero of Cholce to changing attitudes towards human nature. During the Age of Reason, Alexander Pope's "the proper study of mankind is man" was representative of the supremacy of the group to the individual. He was speaking of Man as society and thought as many did that society itself could be both mover and moved. The latter is possible, but the former is highly doubtful. With the devaluation of God and religious constructs as purveyors of morality and ethical guidance, society was substituted in the hope of filling the gap. However, whereas society may be capable of determining proper behavior, manners, or etiquette it is totally incapable of producing a permanent determination for the moral and ethical justification of that behavior. That society. is incapable of supplying the individual with moral guidance, became clear when the individual need to differentiate between "good" and "evil" ran head on with the moral impotence of society at the beginning of the nineteenth century. One of the many characteristics of the romantic movement is the increasing importance of the individual as an ethically valid principle of that differentiation. For the first time the individual and the "differentness of men and their opinions" 1 became translated into an heroic construct. This awareness was emphasized by the effect the

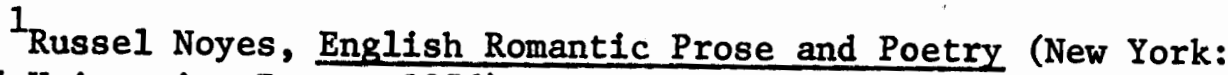
Oxford University Press, 1956), p. xxi. 
Industrial Revolution had upon the lives of many people. William Blake, William Wordsworth, and Samuel Taylor Coleridge were only three sensitive people who were shocked by the inhuman trend they saw about them. Consequently, they sought to reaffirm the values of the individual: love, compassion, and sympathy for mankind (humanitarianism), the essential greatness of men's souls, and the power and strength of nature and natural man. In doing so, the concept of choice was added to the hero. This choice is always presented as one between "good" and "evil" and is readily identified with the way the early romantics felt about the evils of technology.

Like the feelings of those early romantics, the choice of the Hero of Choice is somewhat selective. Although all pervasive indictments of society may be made, the actual evil is usually only one aspect of soclety. The desire of the revolutionary, the complete overthrow of established order and disapproval of all institutions, is not the case. To William Blake this selectively targeted evil is most readily represented by the role Urizen plays in his myth. A multipurpose symbol covering the entire spectrum of ills in society, Urizen also serves as a specific symbol for a dissociation of the psyche, a condition in which the rational part of man has achieved a dominating position. This domination is thought to be the cause of the dehumanizing trend society was taking. Blake sought to recover a state of equilibrium, of balance. The questions he raised were questions of balance, and this balance could not be restored by the continuing development and dependence upon the machine and the factory. Los, Blake's Hero of Choice, strives to recreate the spirit of man in its original unified form, whereas both the machine and the factory under 
the appellation technology, and the rational and linear thinking of science become interchangable terms for the negative effect of Urizen. It is not all of society that must be overthrown, only the worship of technology and of Urizen as God and deity. Society, it is assumed, will realign itself should such a change be accomplished.

In modern works of fiction we see quite frequently this pattern of a choice between a "good" alternative to the "evil" of science and technology. In C. S. Lewis' Space Trilogy it is represented as the research center N.I.C.E.; in J. R. R. Tolkien it is the Dark Lord, Sauron and his underling Saruman's association with machines; in H. G. Wells, it appears as the Morlocks; in Charles Dickens and William Morris it is the City and urban society.

What began as an interest in fantasy rapidly developed into a study of these two types of heroes. The impulse to follow through with this particular concept was Influenced by the works of Northrop Frye: Anatomy of Criticism and The Secular Scripture. The study of archetypes seemed to be the most natural approach for these two heroes. Moreover, a definition of archetype which is based solely on dream and infinite ideals as we get from Jung does not readily admit the possibility that new archetypes may be developing. The focus of most archetypal studies is in the past. The Hero of Choice as I perceive him to be, is in the present and in the process of evolution.

Joseph Campbe1l calls for a new modern hero in the final chapter to The Hero with a Thousand Faces." He contends that "the Iines of

2 The Hero with a Thousand Faces, 2nd Ed. (New York: Princeton University Press, 1968) pp. 387-391. 
communication between the conscious and the unconscious zones of the human psyche have all been cut, and we have been split in two." Because of this the old heroes do not offer the certainties of the past. They do not reassure the modern reader that Iffe has both direction and meaning. Consequently, the modern hero must "discover the real cause for the disintegration of all of our inherited religious formulae." This then, is the function of the Hero of Choice.

In summary, the argument is a simple one. Prior to the time of William Blake, the Hero of Success was the dominant figure in all forms of romance literature. After Blake, we have the appearance and further development of the second type, the Hero of Choice. This second herowas more fully realized with the Romantics and was further defined in the period that followed. The Victorians discussed the characteristics supported by the Romantics and several major contributions were made by Victorian writers. Finally, both heroes appear in our own century with equal frequency and popularity.

I have chosen to use the term Hero of Choice to represent the second type of hero because it most readily expresses and emphasizes the major distinction between the two types. Another term, based on an association with existentialism, may occur to the reader. However, I have deliberately avolded the use of this association for several reasons. First, the focus of this study is British literature and rather than include examples from the French, I have confined myself solely to the British. Second, existentialism has become a pejorative term, through meaning many things to many people. Frequently, it connotes a depressing, despairing, and hopeless view of life. Fortunately, the romance presents a view of life in opposition to the "fear and trembling" 
brought to mind by the term existentialism. Finally, even though many of the characteristice I have attributed to the Hero of Choice are equally valid in describing the existential hero, these characteristics are traced not through philosophy but through 11terature. 
CHAPTER II

THE HERO OF SUCCESS

This chapter will deal, primarily, with an archetypal approach to Iiterature. However, where critics tend to use archetypes to make generic distinctions between different literary modes, my use here will be more closely related to the use made by the folklorist of these archetypal images, descriptive details, plot patterns, and character types. The folklorist seeks to discover both the differentness (variations) and the similitude of treatment which these archetypes receive. Cues are found in those similarities which lead to the categorization of tales into groups based upon that sameness. I have taken my cues from similarities also, these consisting primarily of examples taken from works of romance or at least works which express romance concerns. In the romance we find the archetypal plot pattern of the adventurequest of a hero to obtain an object or goal; often, with the assistance of certain sympathetic helpers. This is true of all romances as well as many non-romance forms, especially the novel. So prevalent is this pattern throughout 1iterature that even Northrop Frye, in his The Secular Scripture: A Study of the Structure of Romance is forced to admit that, "Romance is the structural core of all fiction: being directly descended from folktale, it brings us closer than any other aspect of literature to the sense of fiction... as the eplc' of creature man's vision of his 
own Iife as quest." 1

Once this pattern is recognized and if one accepts Frye's statement as true, one may ask where this leads? How are we to distinguish different forms of fiction if ultimately all is reducible to the romance plot pattern? The method for making those distinctions is the same as those that have always been used. They are the embellishments and variations an author of a given age chooses to give to the basic pattern. When those additions reflect an heroic age and contain tragic seriousness, high achievement, unity, dramatic speeches by the characters, and such characteristics of the epic, the work becomes an epic. When it deals with the ordinary or contemporary setting, Frye's "low mimetic" or "Ironic" heroes, and strives for verisimilitude, the work becomes a novel. When a work deals with a god or man in interaction with gods, the work is called myth. There could be a long list of recognized modes, but the underlying story may be essentially the same. When it is the same story this story is an archetype. We respond to it as such and should distinguish the good epic from the poor, the good novel from the bad, or the well written romance from the poorly written, on the basis of the ingenuity and artistry which the author brings to the basic pattern.

The basic pattern of the actual journey with the hero's episodic adventures, chance encounters, trials, and battles is not our concern here. The manner of beginning that journey is what sets one quest apart from another. More important, the beginnings of these adventures distinguish two types of heroes. These two types will be termed the Heroes

Northrop Frye, The Secular Scripture: A Study of the Structure of Romance (Cambridge: Harvard University Press, 1976) p. 15. 
of Success and Choice.

The first of these, the Hero of Success, is representative of the traditional hero of epic and romance. The second is the result of a change in attitude toward the hero specifically, and man in general that occurred in the nineteenth century. The development of this second type will be dealt with in a later chapter. Here it is necessary to consider only the Hero of Success.

This hero may be a prince, like Beowulf and Ulysses; a knight, like Gawain and Lancelot; or even a child as in the case of fairy-tale characters. Epic may demand that the hero be of noble birth and the characters of fairy-tale may often be of high rank, but this is not necessary for the distinctions I am making. Instead of class distinctions, the Hero of Success is determined by the quality of his actions. He is a character of action. Once the adventure is begun, this hero grapples with monsters, battles with enemies of his own kind as well as with some that may be supernatural or have supernatural aid. When physical violence is not sufficient to overcome the obstacle, the hero may resort to cunning and trickery.

Northrop Frye discusses both forms of activity. ${ }^{2}$ The distinction he seeks, in his examination of Forza and Froda (violence and fraud), is between the literary forms of tragedy and comedy. His discussion is undoubtedly valid and readily apparent in The Iliad, "the story of the wrath (nemis) of Achilles," and The Odyssey, "the story of the guile (dolos) of Ulysses." Yet this generic distinction should not confuse 
the issue here. The activity displayed by the Hero of Success may take both forms. He may be a tragic or a comic figure in the sense that Frye explains them. The pattern for both tragedy and comedy is one of a serles of adventures, combats, tests and trials over which the hero triumphs. This aspect, winning, and its social context is what ylelds the name Success Hero. If he did not win he would not be a hero. Consequently, both forms of activity are available to him and quite frequently a given hero may utilize both at different points during the story.

When he does lose the last battle or fail the final test, as frequently occurs in tragedy, there is even a sense of victory in death. In Beowulf, for example, the death scene is both moving and tragic. It is the death of a great king. Yet death cannot destroy the memory of the man. The Anglo-Saxon ethic, fame, is the equivalent of immortality for the hero who dies valiantly in battle. The mound erected for Beowulf's burial will be known in the years to come as "Beowulf's Barrow," and his people will long remember the "kindest of worldly kings, / mildest, most gentle, most eager for fame." ${ }^{3}$

This sense of victory, even in death, is further strengthened by the fact that the final combat is usually won. The adventure is successful. Wiglaf kills the dragon and takes possession of the gold horde for Beowulf. After the death of Achilles, the Greeks accomplish their goal and sack the city of Troy. Even in Shakespeare's Macbeth, the kingdom is restored when Malcolm ascends to the throne.

$3_{\text {Beowulf, }}$, ed. Charles W. Kennedy (New York Oxford University Press, 1940), p. 101. 
Closely related to the active nature of the Success Hero is the nature of the enemies against which he must fight. Usually they are himan agents representing conflicting social, political, or religious beliefs. The Song of Roland is a good example of this situation. Roland's enemies are the Moslem forces occupying Spain. They are depicted as being aliens; people not only of a different culture and religion, but a different race as well. They exist outside the experience of Roland and Christian France. The combats which occur between prince and prince or one knight and another are external. Heroism becomes an end in itself and single combat proves the valor and strength of the hero.

Similarly, when the antagonist of the Hero of Success takes on the characteristics of the supernatural, that being is seen as a symbol for something outside the experience of the hero. Beowulf fights Grendel and Grendel's mother and the dragon. Symbolically, they represent those natural forces which are hostile to man. Grendel's descent from Cain is intended to show the innate evilness of his very existence. The wilderness in which he lives is as wild and evil as himself. In this wilderness the order and reason man brings to his human community is not only threatened, but under open attack. The precarious position of human society on this planet is a reoccurring theme in Iiterature. The wilderness and the beings that live there are symbolic of the disasters of nature; famine, flood, and freezing winters, that could displace the tentative foothold of man. In all cases, these forces are outside the Hero. They represent the traditional bellef that man's greatest challenge is the mastery of his environment. Not only must he secure his position within the boundaries 
of his small tract of land, but he must defend it against all outsiders. This attitude continues with decreasing popularity to the present day.

To this point only two characteristics have been considered. The first is that the Hero of Success is active. This in itself is nothing new and has, in fact, been long recognized. However, the fact that he may display his active nature in both forms, violence and guile, may be something of a different approach. Since this hero can and does behave in both manners, he transcends the normal boundaries between tragedy and comedy. The second is that the world of the Success Hero is divided into "us" and "them." His perception of the world is limited to the society which he represents and the values and virtues he embodies are good. All else is "out there" and by definition is evil or at least highly suspect of evilness. Because everything not "us" is "them" and evil, it must be dominated and overcome. With the development of the Hero of Choice, this attitude changes and will be referred to when we come to that type.

As stated earlier, the primary difference between the two types of heroes suggested here, rests upon the manner with which they begin their respective adventure-quests. It is a question of motivation more than anything else.

The Hero of Success derives the motivation and validation for his actions from the society which produces him. He operates from an ethic not determined by him. The term ethic is used here not as merely good and bad, but in the sense of the discipline involving duty and obligation. This ethic is expressed as a "code of conduct" that the hero must adhere to. These codes of behavior vary with the culture which 
produces them. Very often a given code may consist of two different, but mutually agreeable ethics. In the French Romance we find the ethic of knightly heroism blended with the ethic of courtly love. Together they prescribed a definite behavior pattern for the hero. Icelandic Saga incorporates the complicated ideals of valiantry, piracy, biood feuds, and revenge. Njal's Saga is the story of one such feud and how it affected the lives of several generations and innumberable families until the culminating act of the burning of Njal's house. The heroes In this story appear and then disappear as the feud grows to involve and then destroy them. As the member of one family is so swept away another rises to seek revenge. Another code is represented by fame in Beowulf.

The various codes of conduct are what motivates the Hero of Success to get up from his beer, pick up his axe, and go out to split heads. His behavior is so stringently determined by them that for practically any given situation a response can, with certainty, be predicted. The only missing factor is the incident which demands that the hero act.

At times the precipitating incident may be very slight; at others, it may take an incredible amount of persuasion. Whatever the case may be, it usually forces the story told into one of the many conventional patterns. Three of these motifs will be considered here.

In the first of these, the hero begins his quest seemingly with no more effort than it takes to walk to the store. This example is based upon what appears to be the conventional pattern of behavior of young and would-be heroes. When life became dull in father's castle and the weather cleared, young heroes were in the habit of hiring out to other kings. Beowulf displays this kind of behavior. All it takes 
is news of the trouble at Hrothgar's Hall and he is off:

Tales of the terrible deeds of Grendel

Reached Hygelac's thane in this home with the Geats;

of living strong men he was the strongest,

Fearless and gallant and great of heart.

He gave command for a goodly vessel

Fitted and furnished; he fain would sail

Over the swan-road to seek the king 4

The opportunity arrives for him to begin an adventure that will bring him the fame so important to his society, and he takes it.

The same convention is at work in the romance Cliges by Chretien de Troyes. The emperor Alexander, ruler of both Greece and Constantinople, had two sons. The eldest was also named Alexander and the younger, Alis. Like Beowulf, the elder son hears news from a distant land, but rather than of monsters, this is news of King Arthur. Shortly afterwards, he approaches his father, the emperor, and asks a favor of him. The emperor says: "I grant you your desire; so tell me now what you wish me to give you." Alexander reveals his plan to his father:

I wish to have a great plenty of gold and silver, and such companions from among your men as I will select; for I wish to go forth from your empire, and to present my service to the king who rules over Britain, in order that he may make me a knight. 5

After a brief discussion, the emperor gives in and Alexander sails for Britain. The romance is thus begun. It only remains for the younger

\section{${ }^{4}$ Beowulf, p. 9}

${ }^{5}$ Chretien de Troyes, Arthurian Romances, trans. W. W. Comfort (New York: Everyman's Library, 1914), p. 92. 
Alls to take the throne in Alexander's absence and the birth of cliges to Alexander and Soredamors in distant Wales, for the conflict between uncle and nephew to begin.

A more recent use of this kind of beginning is found in William Morris', The Well at the World's End. Again, a certain king has sons, four to be exact. We are told on the first page:

they longed to see the ways of other men, and strive for IIfe. For though they were king's sons, they had but little world's wealth; save and except good meat and drink,...house-room of the best; friends to be merry with, and maidens to kiss,... freedom withal to come and go as they would; the heavens above them, the earth to bear them up, and the meadows and acres, the woods and fair streams.... 6

In short, they had everything anyone could ask. The kingdomwas "strait," there was no threat of danger from without or within. The only thing they lack is adventure, and the gentle touch of satire in Morris' description makes it clear that they suffer from an over-abundance of boredom.

Yet not all adventures begin as the result of idleness and boredom. The second of these to consider is essentially the desire to regain something lost. The Illad falls into this pattern. Helen was taken by Paris and all of Greece mounts ships to sail to Troy. Similarly, the second part of Cliges is the same retrieval pattern. Instead, of a woman, in Cliges, the object to be regained is the throne the hero rightfully deserves. Another work of Morris is based upon the stolen woman theme. In The Glittering Plain, the hero Halblithe, intends to 
marry the woman known only by the fateful title, Hostage of the House of the Rose. She is kidnapped by a band of roving sea-pirates to become, in fact, what her name implies. The remainder of the story deals with Halblithe's adventures prior to rescuing and marrying the hostage. This pattern of recovery acts as a spring-board to adventure. It Is also the central core of the stories surrounding the search for the Holy Grail. And there is something of recovery in the Christian and Hebrafc myths of the now Lost Paradise. It appears throughout the tales of folklore and even in fairy storles. John Ruskin's The King of the Golden River is based upon the recovery of farm and the enchanted valley lost by the greed and selfishness of the hero's elder brothers. Even Jack climbs the bean-stalk to regain the articles stolen from his father.

The last of these patterns is the purely contractual agreement that occurs at the beginning of many stories. Sir Gawain and the Green Knight is one such story.

The Green Knight gains entrance and disrupts the festivities of a Christmas feast at the court of King Arthur. The court is in its decline and the Knight tests what courage and valor may yet remain with the king and his retalners. After a very revealing and uncomfortable period, Gawain finally accepts the challenge and agrees to the terms the Green Knight proposes. The Green Knight has announced:

Hit arn aboute on pis bench bot berdlez chylder. If I were hasped in armes on a heze stede, Here is no mon me to mach, for my'ztez so wayke. Forpy I craue in $p$ is court a Crystemas gomen. For hit is 301 and Nwe $3 \mathrm{er}$, and here ar zep mony: If any so hardy in pis hous holdez hymseluen, Be so bolde in his blod, brayn in hys hede, pat dar stifly strike a strok for an oper, 
I schal gif hym of my gyft pys giserne ryche,

pis ax, pat is heue innogh, to hondele as hym lykes, And I schal bide pe fyrst bur as bare as I sitte.

If any freke be so felle to fonde pat I telle,

Lepe ly 3 tly me to, and lach pis weppon,

I quit-clayme hit for euer, kepe hit as his auen,

And I schal stonde hym a strok, stif on pis flet,

Ellez pou wyl di3t me pe dom to dele hym and oper barlay, And zet gif hym respite,

A twelmoyth and a day;

Now hyse, and let se tite

Dar any herinne o3t say: 7

The stroke is struck and the Green Knight leaves with his head in his hand. The "beheading game," as it is often called, is common to many stories. In early Celtic Literature it occurs in an episode involving Cuchulain. Again the Arabic frame story of Thousand and One Nights is a variation of the "game" often found in fairy tales. Scheherazade must tell a story each night that will so enthral the King that he will not have her killed in the morning. She employs the cliff-hanger technique, thereby keeping the King's desire to hear the next night's installment at a higher level than his desire to have her killed the next morning. Scheherazade engages in this rather dangerous situation as an agreement with her father.

Another instance of this contractual pattern occurs in "The Wife of Bath's Tale." The "lusty bachelor" of Arthur's court raped a poor young maiden and was condemned to death. The method of execution is, of course, beheading. However, before this can happen the queen and her ladies plead with Arthur for his life. His life is then placed in

7 Sir Gawain and the Green Knight, ed. J. R. R. Tolkien and E. V. Gordon, 2nd ed., ed. Norman Davis (New York: Oxford University Press, 1968), p. 8-9. 
their hands "to chese wheither she wolde hym saue or spille."

To the knight, she explains:

Thou standest yet.... In swich array

That of thy lyf yet hastow no suretee.

I grant thee lyf, if thou kanst tellen me

What thyng is it that wommen moost desiren.

Be war, and keep thy nekke-boon from iren!

And if thou kanst nat tellen it anon,

Yet wol I yeve thee leve for to gon

A twelf-month and a day, to seche and leerz

An answere suffisant in this mateere;

And suretee wol I han, er that thous pace,

Thy body for to yelden in this place. 8

The knight agrees to this proposal and searches the year-and-one-day

for the answer to her question. At the end of that time he returns

to the court, thereby fulfilling his part of the contract.

These then, are the characteristics of the Hero of Success.

First, his active nature inherent in the very concept of an adventure-

quest, though this activity can be both physical violence and thought-

ful cunning, for both end in the successful completion of the quest.

Winning can even transcend death. Death alone, is not defeat. Second,

the battles the heroes must fight are against beings and forces which

represent the otherness of all that is not the hero. The world outside

the hero's social and cultural framework is alien. It is conspicuous

by its hostile and threatening relationship to the hero's future exist-

ence. Finally, the Hero of Success acts in reaction to one of many spe-

cific precipitating events which necessitate an equally specific and

culturally defined behavior pattern. The differences between the Hero

${ }^{8}$ F. N. Robinson, ed. The Works of Geoffry Chaucer, 2nd ed. (Boston: Houghton Miffin Co., 1957), p. 85. 
of Success and the Hero of Choice will be shown in relation to these characteristics in the following chapter. 


\section{CHAPTER III}

THE ROMANTIC LEGACY: THE HERO OF .CHOICE

The preceding chapter dealt with the Hero of Success. The suggestion there was that he was the dominant form of that earlier period. However, a different attitude evolves with the development of the Romantic Period. In the introduction to English Romantic Prose and Poetry, Russell Noyes explains this change as, among others, the change "from a concern with the species to a concern with the individual" and "from the uniformity of behavior to the differentness of men and their opinions." 1 The emphasis upon individualism produced a new ethic for the exploits of the hero. The earlier age is characterized by the concern for the species, group, or tribe, with a heroic principal based upon the culture which produces him. As such, culture must ultimately accept the laurels of his success and the responsibility for his defeat. This cultural context is the aspect overturned by the revolutionary emphasis upon the individual of the Romantic Age.

The Hero of Cholce is first and foremost an individual. He accepts the responsibility for his victories and his defeats, not his society. The sum of his activity reflects the philosophical question of whether or not man will continue to let culture define and determine what an individual may be. Storles dealing with him are stories which 
either develop this awareness or deal with his exploits after having chosen.

In 1822, Sir Walter Scott, for example, wrote The Fortunes of Nigel. This is one of a group of works that have become known as the Waverley Novels. In this work we find the essence of the Hero of Choice. At a particular point, the Hero is told by Martha Trapbois to see to his own comforts and be more independent. This comes at a point well along in the narrative. We have seen Nigel carried along by events from one episode to another, never exerting himself in these adventures. In fact he has very little awareness of why these incidents have happened to him. Several characters, George Heriot, Margaret Ramsay, and Dalgarno, are more aware of his business than he is. Upon reflection of the advice given him by Martha, Nigel engages in this rather lengthy soliloquy:

'She is right, and has taught me a lesson I will profit by. I have been, through my whole life, one who leant upon others for that assistance which it is more truely noisle to derive from my own exertions. I am ashamed of feeling the paltry inconvenience which long habit has led me to annex to the want of a servant's assistance - I am ashamed to have suffered the same habit of throwing my burden on others, to render me, since I came to this city, a mere victim of these events, which I have never even attempted to influence--a thing never acting but perpetually acted upon--protected by one friend, decelved by another; but in the advantage which I have received from one, and the evil I have sustained from the other, as passive and helpless as a boat that drifts without oar or rudder at the mercy of the winds and waves. I became a courtier because Heroit so advised it - a gamester because Dalgarno so contrived it - an Alsatian because Lowestoffe so willed it. Whatever of good or bad has befallen me, hath arisen out of the urgency of others, not from my own. My father's son must no longer hold this facile and puerile course. Live or die, sink or swim, Nigel 0lifaunt, from this moment, shall owe his safety, success, and honour, to his own exertions, or shall fall with the credit of having at last exerted his own free agency. I will write it down in my tablets 
In her very words,-- "The wise man is his own best assistant." ${ }^{2}$

Rather than be moved by the exertions of friends and enemies, Nigel decides to take the responsibility for his own actions. Alexander Welsh cites this same passage in his discussion of what he called the Passive Hero. 3 However, there is more at stake here than simply the activity and passivity of the hero. As Welsh himself says: "Nigel indicts not so much his own character as the entire fiction within which he finds himself."4 Such an indictment transcends the simple question to act or not, but brings into play "free agency" and centers upon the question of why act or not act. Nigel chooses to act for himself and not in the manner that others expect or advise him to act. The earlier greeks, Ulysses and Achilles, tried to do the same but their efforts were thwarted by the power of popular opinion. Ulysses feigned madness in order to remain at home. Achilles hid, dressed as a woman so that he should not go. But, both were discovered and forced to join that tapestry of events surrounding the fall of Troy.

Nigel's assertion of his own individuality leads him to choose to surrender himself to the authorities. His friends had arranged for a boat to take him down river to board a Scottish vessel and from there to safety and exile. His decision was to act as his own

2 Walter Scott, ed., The Waverley Novels (Philadelphia: J. B. Lippincott \& Co., 1879), ivi, vol. II, p. 82.

3 Alexander Welsh, The Hero of the Waver1y Novels (New Haven: Yale University Press, 1963), pp. 30-58.

${ }^{4}$ Ibid., p. 33. 
conscience dictates, and he decides to be landed at Greenwich and there to surrender. The exchange between Nigel and the boatman is a perfect example of the difference between the man who seeks to avoid responsibility and the man who accepts it. The boatman had been charged with conveying Nigel to the waiting ship and argues with Nigel when he desires to be set ashore. The boatman does not care what will happen to Nigel. His concern is his own skin. A solution is finally found:

My choice is made, said Nigel. I have told you thrice already it is my pleasure to be landed at Greenwich.

Write it on a plece of paper, sald the waterman, that such is your positive will; I must have something to show to my employers, that the transgression of their orders lies with yourself, not with me. 5

With the paper in his hand, the boatman is safely released from responsibility for the change in the plan. An act of individual will is seen as a "transgression." Invariably, the one response the Hero of Choice may count on is the unpopularity of his decision. It always places him in a position opposite to that of popular opinion. His quest becomes all the more difficult for $1 t$, since only others like himself are capable of understanding what the issues are.

The major issue at stake is the issue of the individual. Joseph Campbell had said of the old heroes, "All meaning was in the group, in the great anonymous forms, none in the self-expressive individual."6

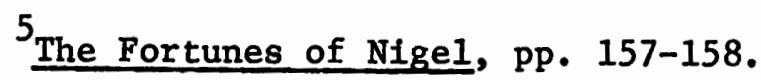

6 The Hero With a Thousand Faces, 2nd ed. (New York: Princeton University Press, 1968), p. 388 . 
He continues saying that today "no meaning is in the group--none in the world." For Campbell all meaning resides in the individual, and it is the quest of the hero to discover what that meaning is. The Hero of Choice is distinctly separated from the boatman and the Hero of Success in that he does not allow his "employers" or his culture to determine the direction or behavior he takes.

Within this context William Blake makes an important contribution. If the individual determines the direction in which society should move, then he must be privy to some information the masses do not have access to. Campbell explains that, not only does modern man not know the direction he is going, but also does not know what it is that drives him on. 7 The Hero of Choice must confront both. Scott's Nigel has concluded that others have been propelling him. He then determines to do his own propelling in the direction of discovering what all this business is about. With Blake it is not so simple, but the idea of regaining one's lost inheritance is essentially the same. The motif of recovery is a dominant theme to the Hero of Choice, but unlike the Hero of Success it is based upon awareness of alternatives and free choice.

Blake was a poet, prophet, visionary, and rebel. His contribution and legacy is the myth he created and the influence this myth has had upon man's thinking since. The myth is a system which attempts to describe both the direction man is going and the principle which moves him along.

To Blake there are two states of being, innocence and experience. Innocence is characteristic of the child and as Northrop Frye explains it: 
In innocence there are two factors. One is an assumption that the world was made for the benefit of human beings, has a human shape and a human meaning, and is a world in which providence, protection, communication with other beings, including animals, and, in general 'mercy, pity, peace and love,' have a genuine function. The other is the ignorance of the fact that the world is not like this. 8

As the child grows and his education progresses he learns that the world is not as he perceives it. Ignorance is replaced by knowledge. What is real "comes from outside the human body" and the human condition. This new knowledge, the realm of experience, creates a world completely beyond human comprehension. This world must be studied and observed in order to be understood. That aspect of the Hero of Success which perceives the world divided between the "Us" and "Them" comes to mind here. Only here this separation is even stronger. The world and man's relation to it are as the relationship between scientist and specimen; the observer and the thing observed.

Where Innocence is a dream of Adam and Eve in the garden, experience tells us that dreams do not, and in fact, never did exist. Consequently, instead of returning to the garden we must desire death. Instead of the garden, experience tells man, there is a heaven. Instead of returning to the unfallen state, after death we will be united with the infinite.

The primary symbol for innocence is the child and a dreamlike state. Others are indicative of a state of purity and unspoiled beauty: flowers, clouds, and lambs. Experience is repersented as Urizen, the old man.

${ }^{8}$ The Stubborn Structure: Essays on Criticism and Society (Ithica:

Cornell University Press, 1970), p. 175. 
This may often be thought of as reason, science, organized religion, and adulthood. The frustrated dream state of innocence is symbolized as Orc, the young revolutionary. 9

Orc and Urizen are constantly in a state of open conflict. The story of their conflicts is the cyclical history of the world. 10 As the youthful orc appears and begins his campaign for freedom from the tyrannical rule of Urizen, his energy is gradually subverted and diffused on the rocky promontory of established order and reason that is Urizen.

However important this conflict may seem neither Orc nor Urizen is exemplar of the Hero of Choice. Urizen maintains the status quo. He is the "employer" of the boatman we have seen in Scott. Under his rule man will forever remain in the fallen state. Orc in his flery rebellion is pure "transgression." It is his nature to be a revolutionary and he does so purely for rebellion's sake. He is not the hero who chooses. He thinks the garden can be returned to, but, as Frye explains "we recover our original state; not by returning to it, but by re-creating it."11 There is, in Blake's mythology, Los, third figure, who symbolizes this creative impulse.

In his poem "Milton," Blake identifies himself with two figures. The first is Milton. The second is Los.

While Ios heard indistince in Fear, what time I bound my sandals

On to walk forward thro' Eternity, Los descended to me:

${ }^{10}$ Ibid, pp. $181-82$.

11 The Stubborn Structure, p. 199. 
And Los behind me stood, a terrible flaming sun, just Close behind my back. I turned round in terror, and Behold!

Los stood in that fierce glowing fire, \& he also stoop'd Down

And bound my sandals on in Udan-Adan; trembling I stood

Exceedingly with fear and terror, standing in the vale

Or Lambeth; but he kissed me and wish'd me health,

And I became One Man with him arising in my strength.

'Twas too late now to recede. Los had enter'd into my

Soul:

His terrors now posses'd me whole! I arose in Fury \& strength. 12

The character Los has the ability to re-create the original state from which man has fallen. Los is:

the Impulse to transform the world into a human and imaginative form, the impulse that creates all art, all genuine religion, all culture and civilization. This impulse is personified by Blake as Los, the spirit of prophecy and creativity, and it is Los, not Orc, who is the Hero of Blake's prophesies. Los derives, not from the suppressed desires of the individual child, but from a deeper creative impulse alluded to in Biblical myths about the fallen state. 13

The spirit of Los enters the "soul" of Blake and it is this spirit which guides the poet. In this possessed state, the poet becomes one of the enlightened few, one of those visionarles who transcend the normal condition of humans. He has escaped the ever repeating cycle of conflict between Orc and Urizen, to the vision of the true infinity. This is the objectively invisible world in its "human and imaginative form." The responsibility of the enlightened few who make this discovery is

12 William Blake: The Complete Writings, ed. Geoffrey Keynes (New York: Oxford University Press; 1974), p. 505.

${ }^{13}$ Stubborn Structure, p. 196. 
to make this vision known to the masses, the unenlightened. The only alternatives to the realization of this vision are the apocalypse of a successful Orc or annihilation at the hand of Urizen. ${ }^{14}$

The Hero of Choice is the embodiment of the spirit of Los. He combines the desire for the dream with the creative impulse. He acts against the dominance of Urizen and the unthinking irresponsible rebelIion of Orc. He symbolically strives to re-create the dream. It should be remembered here that the dream represents the unfallen state. In Blake's belief that unfallen state is a completely integrated psyche. It was to be an integration not only of the several parts, but an integration of those parts with the world as well. The usual antagonist for the Hero of Choice is an uncontrolled superego, a Urizenic figure symbolized by its evil tyranny, Inhumane acts, a combination of science and technology. These same qualities were the focus of Blake's own criticism. They were turning his London into a soot heap already at the end of the eighteenth century. It was Urizen who was forcing young boys to shave their hair, strip of $f$ their clothes, and climb down the blackened chimneys of Industrialized England. Blake's myth shows us that the direction we should be going in, is opposite to that which science and technology are leading. It further explains that ultimately this goal is the unfallen state, the well coordinated human psyche. The propelIing force behind this quest is the spirit of Los. The Hero of Success can never accomplish this feat. Riden and driven by his overpowering sense of culture and dependency on the group, his successes are the

$$
{ }^{14} \text { Ibid. , p. } 198 .
$$


successes of Urizen over Orc. Thereby he completes one cycle only to begin another. Only the Hero of Choice unconfined by society and able to exercise his own free will is capable of achieving the desired results. His battles are fought against forces which symbolize the disparate parts of himse1f. His greatest challenge is no longer his environment, but the discovery of himself. 
CHAPTER IV

THE VICTORIANS

The Victorian Age is a period of vast complexity, complexity in literature as well as society. As the industrial revolution increased the population of the urban centers, the inttial allure of progress dissolved in the realities of factory and slum. The evils that Blake had prophesied were all about. Worst of all, there was no one around to blame. The problems the Victorians faced were different from those of pre-nineteenth century men. The belief in the supremacy of the group, inherited from the age of Alexander Pope had set elements of society in motion that by the end of the $1830^{\prime}$ s were well out of control. The dragon of uncontrolled industrialism had sprung not from outside England but from within. The new monsters of the modern world were realized to be products of man's own weakness, his inability to know himself and to deal with the problems his society created. The greatest challenge was no longer the subjugation of the environment, for it was readily apparent that since man was capable of both mastery and destruction, the new challenge became man himself. At issue was the direction the then existing industrialism was leading and the moral authority for behavior under the dominion of this new development.

In light of such concerns the literature of the age abounds in social criticism. There were no institutions immune to the questioningly critical pen of the writers. In fact, a certain amount of criticism was expected by the reader. This does not mean that everything written was 
critical of society's developments. An equal amount of time was spent in praise of the progress and flourishing wealth that England was experiencling. These sides were equally represented; and many more than these existed. However, it is not my purpose to sort out all the controversies that existed during the period. Instead, I wish to follow the two types of heroes as they appear at this time and show how they were an important part of all that was happening.

The general reaction on humanistic terms against the technological short-sightedness of the age, foreshadowed by Blake's attacks, is evidenced in many works among which perhaps Charles Dickens' Hard Times is a good example. His description of Coketown is intended to be the picture of a typical industrial center. It is a "town of unnatural red and black like the painted face of a savage" in which "serpents of smoke trailed themselves for ever and ever, and never got uncoiled." ${ }^{1}$ Later:

The fairy palaces burst into illumination, before Fall morning showed the monstrous serpents of smoke trailing themselves over Coketown. A clattering of clogs upon the pavement; a rapid ringing of bells, and all the melancholy mad elephants, polished and oiled up for the day's monotony, were at their heavy exercise again. 2

The metaphors lend an air of unreality as well to the unnaturalness of the town. Those "elephants" in their "heavy exercise" were as capable of trampling their operators as they were of producing endless coils of polluting smoke.

$1_{\text {Hard Times }}$ (New York: W. W. Norton \& Co., 1966), p. 17. 2 Hard TImes, p. 58. 
The characters which appear in Hard Times are equally deficient in humanity. Josiah Bounderby, the successful factory owner, is completely immune, even callous, to the suffering of his employees. Success measured in terms of his increasing wealth is all that concerns him: Richard Altick says of him "the prestige value of the myth of success against impossible odds is suggested by the trouble to which Bounderby... went to invent the cock-and-bull story of his heroic triumph over his gutter origins." 3 More important here is the fact that Bounderby represents the movement of the Hero of Success into the nineteenth century. But Bounderby is only one aspect of the Success Hero. He is the extension of social values to their logical conclusion, particularly the emphasis on material and economic wealth as sole determinant for goodness. Because his nature is founded upon the myth of success without any human consideration or warmth, he becomes. a villain from Dickens' point of view. The social novel produced this type of villainous hero because of its critical nature. Romance, however, continues to present the positive and "good" Hero of Success of Beowulf and the others. But from Bounderby. to Irwin Shaw's RIch Man, Poor Man is only a matter of time and the refinement of social realism. The economic Hero of Success has never disappeared.

Dickens' Gradgrind is an equally repulsive character. As a representative of Benthamism he represents the utilitarian aspect of moral authority. As industrialism destroyed man's soul and spirit through the Inhuman treatment of his body, the same was occurring through his 
mind. Eventually Thomas Huxley's world of natural science will destroy the old philosophical and ethical constructs and replace them with a world in which nature was all order. Absolutely nothing could or did interfere with that order. This new concept destroyed in two ways; first, it replaced the order of God with the order of nature, a situation which forced Huxley to coin the term agnostic; and second, by destroying all literal interpretation of the Bible through the works of Lyell in geology and Darwin in biology, it killed God, or at the very least pushed Him so far back in the scheme of things as to make Him Ineffectual. The "deeds and prayers of men" were now for nothing-wasted effort--for if God was still in the universe He had become as the dice thrower, and just as impotent after the throw. In such a situation, Thomas Carlyle had been forced to view the universe robbed of "Life, of Purpose, of Volition, even of Hostility: it was one huge, dead, immeasurable Steam-engine, rolling on, in 1ts dead indifference... ." 4 For Carlyle, who felt the need for faith, even the humanism of John Stuart Mill was not sufficient to fill the gap. Any doctrine which based itself on the newly exalted position of Man, the logical conclusion in a world which has jettisoned God, was highly questionable in the light of the discoveries of Darwin. Such propositions as Darwin's on the ancestry of Man, even though he had not intended them as such, could be and were, fatal to faith, and through faith, all moral basis for behavior.

4Thomas Carlyle "The Everlasting No" in Victorian Prose and Poetry, ed. Lionel Trilling and Harold Bloom (New York: Oxford University Press, 1973), p. 21 . 
The question is one of where authority for moral behavior is found if it can no longer be ascribed to God. As Lionel Trilling explains it; "The central issue of Victorian culture was whether society was to be regarded as a spiritual entity or as a material and mechanical entity. " 5 This issue was the impetus behind the rise of so many isms. Benthamisth, Evangelicalsim, Christian Socialism, and Humanitarianism were all attempts to prescribe the way men should live and the way society should behave toward men. So strong was the need for moral authority that it permeated the whole of Victorian Society. It is not surprising that Matthew Arnold remarks in "Stanzas from the Grande Chartreuse" that life is "Wandering between two worlds, one dead,/ The other powerless to be born." In Charles Dickens' Christmas Books, "A Christmas Carol", and "The Chimes," and the others, he tried to supply what he considered to be moral lessons for right behavior. Dickens' works abound in social criticism, including for example industrialism and Benthamism in Hard Times and the judicial system and the aristocracy of Bleak House, and yet, we find a humanism in all his novels that is based upon men dealing ethically with their fellow men. One source of that humanism comes from a surprising quarter. One has only to turn to M. C. Kotzin's Dickens and the Fairy Tale (Bowling Green: Bowling Green University Press, 1972) or Angus Wilson's The World of Charles Dickens (London: Secker and Warburg, 1970) to see their remarks about the extensive use Dickens made of the fairy tales in his novels. In an essay entitled "Frauds on the Fairies" in The Collected Papers (Bloomsbury: The Nonesuch Press, 1938) Dickens

\footnotetext{
${ }^{5}$ Victorian Prose and Poetry, p. 9.
} 
defends the tales in humanist terms:

It would be hard to estimate the amount of gentleness and mercy that has made its way among us through these slight channels. Forbearance, courtesy, consideration for the poor and aged, kind treatment of animals, the love of nature, abhorrence of tyranny and brute force-many such good things have been first nourished in the child's heart by this powerful aid: 6

Compare this defence with the summation of Sissy Jupe at the end of

Hard Times --

She [Sissy], grown learned in childish lore; thinking no innocent and pretty fancy ever to be despised; trying hard to know her humbler fellow creatures, and to beautify their lives of machinery and reality with those imaginative grace and delights, without which the heart of infancy will wither up, the sturdiest physical manhood will be morally stark death, and the plainest national prosperity figures can show, will be the writing on the wall, - she holding this course as part of no fantastic vow, or bond, or brotherhood, or sisterhood, or pledge, or convenant, or fancy dress, or fancy fair; but simply as a duty to be done,.... 7

and both the theory and practice of Dickens' humanism is clear. The values he discovered in the fairy tale were utilized by him as a weapon in his attack on the Bounderbys and the Gradgrinds. The evils and ugliness of modern Iffe can be dealt with if one behaves from the "gentleness and mercy" which is the naturally good side of man.

Dickens understood that this natural goodness is transmitted to children and adults through fairy tales. These values are much older

6 The Collected Papers, p. 463.

7 Hard Times, p. 226. 
and more essential than those offered as solutions in his utilitarian age. As such they are reminiscent of Blake's unfallen state. Furthermore, because they deal with essential problems of human interaction, much could be learned from them. He also understood that their value necessitated that they be kept "pure" and not be rewritten to present more modern concepts. In keeping with this "purist" approach, Dickens did not rewrite tales to suit his own ends, instead, he borrowed motives and archetypes which were easily recognizable to his readers and used them to enhance his novels.

"The Christmas Carol," however, represents Dickens' humanism in its most open and straightforward aspects. The story of Scrooge obsessed by his miserly lust after wealth, and the change of heart representing his conversion to benevolence and good works is not really a fairy tale. Instead, it is a story which advocates adherence to humanitarian ideals and the morally right behavior stemming from those ideals. As such, Dickens' Christmas stories are vehicles for social criticism rather than fairy tales. They are closer to Aesop--less the animals-and so are moral fables. As Michael Slater says in his introduction to the "Caro1," Dickens intended to bring home "to the better off the plight of the poor, especially the children" in such a manner that it "would be a thousand times more powerful than any pamphlet." 8 What the fairy tale could do for the moral education of children, the highly moral Christmas Books could do for Victorian adults.

8"The Christmas Carol" in The Christmas Books, Vol. 1; (Baltimore: Penguine Books, 1971), p. 34. 
Dickens' second story, "The Chimes" was similarly concelved. The target of his criticism in this, however, was the then prominent theories and attitudes held by both the upper and the middle classes which conceived the lower class as a problem not human "and at worst born bad naturally vicious and depraved." 9 Mr. Filer represents the utilitarian attitude of the middle class. His soliloquy on the waste of eating tripe is a masterpiece of the calculating machine approach to determing proper behavior, and "the greatest good." In his opinion if the lower classes would stop eating tripe they would not only better their position economically, but the nation's economy would receive a boost from the elimination of such wasteful behavior. Filer's partner in crime is Sir Joseph who represents the fatherly attitude of the Aristocracy. Dickens seems to have had Thomas Macaulay in mind when Sir Joseph describes himself as the "Poor Man's Friend and Father; and I endeavour to educate his mind, by inculcating on all occasions the one great moral lesson which that class requires. That is, entire dependence on myse1f."10 But when it comes to actually lending the assistance so sorely needed to those less fortunate, he flatly refuses. It is Toby's misfortune first to be poor and second to be trapped between these theorfes and attitudes. The lesson he must learn is that we "must trust and hope, and netther doubt ourselves, nor doubt the good in one another." The lower class can only hope in themselves, for none will come from the classes above. Like Scrooge, Toby is redeemed by the change of heart

\footnotetext{
9"The Chimes" The Christmas Books, Vol. 1, p. 138. ${ }^{10}$ Ibid, p. 183.
} 
which makes the most of what he does have, and through which he treats his fellowmen with "gentleness and mercy."

Dickens' humanism was not the only direction Victorian critics thought the quest of modern man should take. Another was the way some of them felt about the Middle Ages. T. H. Huxley expressed this feeling in his "Science and Culture." He explains that in the Middle Ages men:

were told how the world began, and how it would end; they learned that all the material existence was but a base and insignificant blot upon the fair face of the spiritual world, and that nature was, to all intents and purposes, the playground of the devil; they learned that the earth is the center of the visible universe, and that man is the cynosure of things terrestrial... il

The appeal here is to the appeal of the Hero of Success. The phrase "man is the cynosure of things terrestrial" was interpreted by John Ruskin, William Morris and the Pre-Raphaelites as man in group relations. They admired the security and lack of emotional conflict one derives from being completely determined by the culture of which one is a part. To Ruskin and Morris, the Middle Ages represented a society in which the individual was indistinct and inseparable from the greater group. In this context the Middle Ages were admired for the lack of individuality. Individuality, especially the exercise of choice, breeds dissent and a movement in opposition to society. Consequently, Morris' romances concern themselves with the Hero of Success as he appears in romance, different from the successful characters of Dickens' novels. The characters one finds in The Well at the

11. T. H. Huxley "Science and Culture" in The Portable Victorian Reader, ed. Jordon S. Haight, pp. 486-487. 
World's End lack a proper Identity of their own, separate from the soclety in which they live and for this reason the Success Hero readily lends himself to the stereotype. The reader knows no more of them as people than he does the archetypal character in a fairy tale. But the qualities Morris' characters, Ralph and Ursula, embody are the good qualities most admired by their society. Ralph is wise, noble, fair, and vallant, but beyond that we know practically nothing. He represents the good of the world in which he 1ives, and the problems he must face are those of good and evil in the abstract, not the real problems of human beings. To Morris this was what was important to that earlier age. Both he and Ruskin thought that a return to this was the solution to the problems the Victorlans faced. The "good" of Ralph was representative of the less complicated life of the Middle Ages and the "evil" was the complicated life of modern society. When it comes to Morris' later Utopian works the same ideal applies. News From Nowhere recreates that aspect of the Middle Ages he most admired.' The society has dominance over the Individual. All decisions are made for individual man and ultimately all responsibility even for individual effort resides in the group. Morris' utopia is benevolent as most utoplas are, just as Plato's republic was benevolent with a price. As there was no room for art as we know it in Plato's society, so there was no room for Individual responsibility in Morris' medieval soclety. John Ruskin thought the same. His admiration of the Gothic led him to conclude that, as concerns art, when the individual is subjugated to the group, the individual is freed to revel 
and take pride in the act of creation. ${ }^{12}$

The dominant trend during this period was that of Morris and Ruskin. But it was also reflected in the great anti-individualistic movements: Evangelicalism and the Oxford Movement. ${ }^{13}$ When it did appear, Individualism took on the lanquid form of eccentricity. Dickens' characters, Miss Haversham and Mr. Dick, are representative of the debilitated nature of individualism in Iiterature during the period. Even David, in David Copperfield, only barely approaches the Hero of Choice. The moments when he asserts himself, as when he leaves his apprenticeship in London are immediately cancelled by his lack of assertion when he is carried along by the Inertia of Steerforth.

All that has been considered to this point applies to the Hero of Success and the thinking which produced him during the Victorian Age. There are examples of the other form in this period as well. However, before we consider them several observations should be made.

Romance went underground in the novels of Victorian England. But as we saw with Dickens, romance, exemplified by the fairy tale, continued to play a part in the social novels of his age. It was a minor part, granted, but still a part. The fairy tale was not considered proper reading for adults and even when read to children, it was thought that expurgation of all questionable material was necessary before they should be read. Consequently, when Dickens chose to champion the 1deals which

12 See Ruskin's remarks in "The Stones of Venice" Victorian Prose and Poetry, pp. 176-180.

${ }^{13}$ Altick, pp. 185-86, 211. 
they contain, he was forced by his own desire to achieve success to submerge and disguise those Ideals in his novels, as in Great Expectations. And yet, those 1deals which are the basis of Dickens' humanitarianism are the most attractive features of his novels.

This lack of romance as a valid form is important when dealing with the heroes of Success and Choice, for when romance and romance elements are not acceptable in literature, the Hero of Choice becomes practically non-existent. It is evident from the Victorian experience that choice is dependent on the romance for its existence, whereas success is not so dependent. As the age closes and romance again becomes a legitimate form of expression, the appearance of the Hero of Choice is proportionately more frequent. Both Success and Cholce may appear in romance, but Cholce must have romance. It is romance that leads to the concept of quest. Quest not in terms of socially sanctioned striving after success or success measured in terms of economic and material gains as we saw in so many of Dickens' villains, but quest in the sense of an inherent moral responstbility. This responsibility is most readily supplied through religious institutions, but when those institutions lose their relevancy to the human condition man is forced to turn elsewhere. Just as Dickens employed the humanistic values of the fairy tale, others turned to various sources. In this sense my argument is open to the charge of having religious grounds, but it is religlous only in that I recognize a need universally to distinguish the "good" from the "evil." This is what romance presents to the reader. The Victorian distrust of the romance is symptomatic of their avoidance of everything not sanctioned by society and yet the irony of their situation was that they also felt the need to discover a basis 
for ethical beliefs; yet instead of romance and myth they turned to soclety, which never could supply it. Their institutions could not address themselves to the moral responsibility of man on other than social terms. And soctal mores are not a sufficient substitute.

Charles Dickens' most romance oriented novel was A Tale of Two Cities. In it we see not only the Hero of Choice in Sidney Carton, but also the Victorian disparity between social goals and the ethical act of the responsible individual. Carton is presented in the novel as a drunken and debauched lawyer. Yet his behavior at the trial of Charles Darnay in the English court indicates that he is in complete possession of his faculties and quite the match of other men. The motivation for his seeming transformation is his love for Lucie Manette. Yet even in this he displys his clear-headedness and perception. He admits to Lucie that because of his reputation his love would "bring you [Lucie] to misery, bring you to sorrow and repentance, blight you, disgrace you, pull you down...."14 And then after vowing never to mention his love again, he makes the promise that he "would give his life, to keep a life you [Lucle] love beside you!"15

Carton has rejected the mores of his society, he has lived a life of self-indulgent extravagence. He is a fallure in his own opinion and a failure from the point of view of society. But when he takes Darnay's place upon the scaffold he becomes a success in terms of both social and individual responsibility. The sacrificial act is not socially

\footnotetext{
${ }^{14}$ A Tale of Two Cities, p. 154.

${ }^{15}$ Ibid. , p. 156 .
} 
prescribed behavior, but society admires such acts even though it makes no provisions for producing this behavior on its own. Romance, motality, Christian love,--here they are all used synonymously--are the means by which Carton makes his choice. The result is not only his success and his redemption, but also his transcendence of the moral wasteland that is his society. He becomes a successful Oscar Wilde, attacking the accepted mores and social standards, and succeeds in transforming his life into art.

Another example of the emergent Hero of Choice occurs in Thomas Hardy's Jude the Obscure. Jude makes two choices. The first is the choice to seek success through education, which is in complete accord with society's standards. The second is the choice made fointly with Sue to live together without the sanction of the marriage ceremony. This second choice is the one that distinguishes both Jude and Sue. But Sue is unable to bear the weight of responsibility for the life she has chosen. As the consequences and guilt increase she seeks relief in orthodox christianity, compromising her individuality and violating the ethics of her choice. She says to Jude:

We must conform! All the ancient wrath of the Power above us has been vented upon us. His poor creatures, and we must submit. There is no choice. We must. It is no use fighting against God!16

But Jude knows that it is not God but man that they fight and unlike Sue, he remains constant to his decision and says, "It is only against

${ }^{16}$ Thomas Hardy, Jude the Obscure (New York: Signet Classics, 1961), p. 337. 
man and senseless circumstance."17

Much has been said concerning Hardy's determinism, but it is a determinism of institutions and not providential. The passage above illustrates that it is the power of social determinism that has been vented upon Sue and Jude. That determinism is what they as heroes had chosen to fight against, and if one reads Jude the Obscure as a struggle against God with both heroes doomed to fallure, the essential heroic quality of Jude does indeed become obscure. Sidney Carton's death was not a failure or doom and likewise neither is Jude's. Jude has chosen to live his life as Carton did, in opposition to the standards of others and in death he triumphs. During his last meeting with Sue after she had succumbed to the suffering and pressure such a life produces, he remarks to her, "you dear, sad, soft, most melancholy wreck of a promising human intellect that it has ever been my lot to behold! Where is your scorn of convention gone? I would have died game!"18

The irony of the novel is that he did "die game" and that because he fought the fight he did, no one will ever know that he even 1ived. Arabella's disregard of his death for the social function of the festival and the "boat-bumping" points out his relationship to society. Soclety will destroy, if it can, and then forget its antagonist. Jude's life, death, and herolc struggle become an obscurity, but the facts remain known to the reader.

$$
\begin{aligned}
& 17 \text { Jude, p. } 337 . \\
& 18 \text { Jude, p. } 384 .
\end{aligned}
$$


CHAPTER V

THE TWENTIETH CENTURY

With the close of the Victorian Age, the concept of the Hero of Choice moved into the twentieth century. However, the emphasis by Ruskin, Morris and the Pre-Raphelites also assured that the Hero of Success would live on into the twentieth century. Modern fiction draws heroes equally from both traditions. Consequently, this and the following chapters will deal with the utilization of specific examples from both.

Although my personal taste tends to make me react more favorably to those works which contain Heroes of Choice, I do not wish to imply that either type is better or has more literary merit than the other. Often, works which deal with choice may be less appealing than those which deal with success. One case in point, is that of Thomas Carlyle's Teufelsdröckh, A Hero of Cholce, and Charles Dickens' David Copperfield, a Success Hero. When carefully presented, both types may be equally appealing and popular.

\section{Sherlock Holmes}

Such is the case with Arthur Conan Doyle's creation, Sherlock Holmes. It is hard to imagine another Hero of Success who has experienced so much popularity or so engaged the minds of readers as has Sherlock Holmes. When Doyle introduced one Dr./Watson to Mr. Holmes in 1886 in the novel A Study in Scarlet, he had no idea that the 
character he had created would be so well received. So infatuated was the public to become, that when, in 1893, The Final Problem appeared, a clatmor was raised that was to hound Doyle for the following ten years. The death of Sherlock so shocked Doyle's readers that they simply would not let him alone. Telegrams, letters, and verbal demands were made for the return of the hero. It is interesting to note that Doyle finally responded in 1902 with a story entitled The Hound of the Baskervilles. The hounding of the Baskerville family was not much different from the hounding of Doyle himself. Since the story was carefully couched as a case as yet unchronicled, it was a compromise on the part of its author, but this concession was still not enough to quiet the public. They demanded nothing less than a live and breathing Sherlock Holmes.

As readers' demands increased, so too, did the demands of the publishers; As John Dickson Carr documents in his bibliography of Doyle, in the spring of 1903 an offer came from America that was to change Doyle's mind. The offer stated:

If he [Doyle] would restore Sherlock Holmes to life, in some fashion explaining away that matter of the Reichenbach Falls, they [the publishers] were prepared to pay him at the rate of five thousand dollars a story for six shortstories or as many more as he cared to write. 1

\footnotetext{
"These were only the American rights." The English publishers were willing to equal the offer.
}

${ }^{1}$ John Dickson Carr, The Life of Sir Arthur Conan Doyle (New York: Vintage Books, 1975), p. 243. 
The end result was that after ten years of pressure, Doyle was forced to resurrect Holmes in a new series of stories, the first of which, "The Adventure of the Empty House," explained "away that matter of the Reichenbach Falls."

Such overwhelming popularity in terms of reader interest and remuneration makes one wonder what Doyle could have done with the Hero of Success to cause such reaction. Samuel Rosenburg's introduction to a recently published facsimilie edition of The Hound of the Baskervilies sheds some light on this question.

Doyle was an avid reader and one of the people he most admired was Edgar Allen Poe. At a dinner at the Hotel Metropole to honor the centenary year of Poe's birth, Doyle acclaimed the man as the "supreme original short-story writer of all time." So great was Doyle's admiration of Poe that, when he first began writing the Holmes stories, he borrowed characteristics from C. Auguste Dupin. Dupin is the hero of such Poe greats as, The Murders in the Rue Morgue and The Purloined Letter. Rosenburg lists these borrowed characteristics as:

A. an advanced intellectual who solves crimes by means of his almost superhuman analytical powers.

B. a detective who sees things that go unnoticed by experts.

C. able to read the inmost thoughts of people by observing "trivial" surface indications like glances, shrugs, eye movements and body language.

D. a double, almost schizophrenic, personality

E. Iives the life of a bachelor whose emotional and sexual energies are entirely sublimated in his philosophical and criminological pursuits.

F. a musician

G. a tobacco addict 
H. addicted also to long self-congratulatory explanations to his entirely platonic roommate.

In addition, the roommate is:

I. a mental inferior

J. the narrator of the exploits in which the detective solved crimes.

Those crimes

K. completely baffle the stupid police detectives. ${ }^{2}$

All of these characteristics appear in the first story Doyle wrote, A Study in Scarlet. If Doyle had left his character there we would have had nothing more than another Dupin; an unemotional calculating machine. If that had happened the merits of the story, the plot, and the telling are what would have carried the work, but Doyle's audience clearly demanded Holmes, not fust another story.

The character of Holmes strays from the original Dupin in proportion to two developments. The first of these is the desire on the part of Doyle for verisimilitude. He did not wish to create a flat and mechanical device to be carried along by plot. Consequently, Doyle added to the list of characteristics cited by Rosenburg. These characteristics increase Holmes' individuality as a hero, but rest upon the extablished groundwork of Dickens' eccentric Miss Havisham and Mr. Dick, rather than the true Individualism of the Hero of Choice. The additions

${ }^{2}$ Samule1-Rosenburg, ed., The Hound of the Baskervilles, by Arthur Conan Doyle (1902; facsimilie rpt. New York: Schocken Books, 1975), p. 1x. 
are Holmes' descent from country squires; his chivalrous attitude toward women (even more than Wastan's); his possession of almost total recall for all facts relating to criminal cases; his belief in neither religion nor the supernatural; his mastery of dialects and philology; his ability to disguise himself so completely that even Watson is unable to recognize him. He accepts cases not for monetary reasons but for their interesting features or urgency, has a highly developed sense of morality and justice that sometimes leads him to act independently of the law; and he on occasion reacts violently with righteous indignation, writes monographs on obscure knowledge; and is patriotic and a firm believer in English society and English tradition.

For the lighter side, Doyle utilized other quirks to establish the eccentric nature of Holmes and a positive response in the reader. When his name is mentioned one pictures Holmes sitting in his dressing gown, never fully dressed when at home in his apartment. His habit of keeping his tobacco in a Persian slipper or target practicing in his room by writing a "patriotic V. R." with bullet holes in the wall, are equally memorable. When engaged in a problem, he sits for hours through the night turning the room blue with smoke from innumerable pipe 1oads, and then, at the scene, crawls on all fours "like a dog" looking and "sniffing" for clues. Each of these details and many others produces a charater more vivid and real.

Doyle created a knight errant, Hero of success, whose quest and deeds required not physical prowess, but a completely rational mind. Together, Holmes and Watson journeyed over England and the Continent like Don Quixote and Sancho Panza. The only difference between the two pairs was that Holmes' giants weren't windmills, but real criminals 
within the context of the fiction. In Doyle's desire for realism, Holmes sometimes failed, as in the case A Scandal in Bohemia. Without the eccentricities and fallures Holmes was too superhuman. What Doyle was trying to do was to humanize the analytic machine created by Poe and make him more believable. Therefore, those habits reflect patterns of behavior only slightly askew.

The second explanation for Holmes' development away from the Poe original is one suggested by Carr. As the subtitle to the biography implies--"The Man Who Was Sherlock Holmes"--it is Carr's belief that Doyle was really writing about himself. Aside from the obvious similarities of descent from country squires, patriotic and cultural beliefs, and disposition, Carr cites the interesting case of George Edalji. ${ }^{3}$ This was an actual criminal case which took place in 1903. Doyle was to be involved with the affair for three years during which Edalfi was wrongly convicted and sentenced for animal mutilation. Using precisely the same methods he ascribed to Holmes, Doyle was able to unravel the mystery,-In the best tradition of Holmes--name the actual criminal, and through his continual pressure on the Home Secretary, secure innocent Edalji's release from prison. A similar case of justice miscarried.was again begun by Doyle in 1912. This one, Involving Oscar Slater, was to last for sixteen years before it was solved and the sentence revoked.

No matter which explanation is used, the fact remains that the character Sherlock Holmes was the beneficiary. After the initial delight over a well written series of detective stories, the readers, like 
Watson, learned more and more about the eccentric individual that was Sherlock Holmes. More important, they learned to love him. He appeared at a time and among a population who were to idolize and revere people like Kitchner and Gordon in Africa and later so romantic a figure as T. E. Lawrence, fighting a war in the land of Arabian-nights. Holmes; successes are the successes of the best qualities produced by English soclety. He represents the belief in the ability of science and rational mind to overcome all obstacles and still remain human. He provides a quality lacking in the world around us. He has overcome the drab greyness of existence that is born of familiarity with our surroundings, nourished by our habits of behavior, and culminates in a boredom that drives the vitality and energy of life from us. When engaged in a case, Holmes was intensely alive, observant of the smallest of things, and energetic beyond his normal physical abilities. His victorles are our victories, the success of each one of us and of our society as a whole.

\section{H. G. We11s: Food of the Gods}

What Arthur Conan Doyle did with his Success Hero, Sherlock Holmes, H. G. Wells approached with his Heroes of Choice in the Food of the Gods. I've chosen Wells' Food of the Gods because of the many similarities that exist between Doyle's Holmes and Wells' Bensington, Redwood, and Cossar. Like Holmes, Wells' characters are all three, men of science. Furthermore, they represent the different divisions of science. Mr. Bensington is the chemist and "pure scientist." Redwood is more the philosophical, and as Wells says of him, "He was different inasmuch as something of the vision still lingered in his eyes." The third is Cossar, the engineer. He represents the practical application of science. Only through the 
efforts of all three, is the food brought before the world. All three are just as dedicated as Holmes to the belief in the ability of science and the rational mind to overcome the problems of society. Where they part company from Holmes, is in the cholce with which they are faced. What begins as a comedy of errors with the development of the food, quickly becomes much more serious. The "accidents" which infest the country side of Kent with giant chickens, wasps, and rats bring the discovery of the food to the attention of the public. More important however, is the attention of the young and promising politician, Caterham. He sees the food as a means of furthering his career. It is Caterham who suggests the total suppression of the food. His attacks in newspapers and Parliament unify the public in opposition to the "Boomfood." His popularity is measured in proportion to the number of societies that appear. Such groups as the "National Society for the Preservation of the Proper Proportion of Things," the "Society for the Total Suppression of Boomfood," and the "Temperance in Growth," a branch of the "National Temperance Association" spring up all over the country. With their appearance, the discoverers of the food are faced with a very important decision.

All three men make the same choice. Redwood summarizes the decision for all of them when he says, "If the worst comes to the worst... I shall give the food to my little Teddy with my own hands." Both Redwood and Cossar had given the food to their children, and other children had received it "accidentally." The giant children caused even more controversy than the earlier outbreaks. Questions of housing, education, national interest, and even the rights of parents to "normal" children were raised. When Bensington and Redwood express their doubts 
about the wisdom of continuing in opposition to public opinion, Cossar quite violently upbraids them for their vacillation: "not to go on with $1 t$ !" he shrieked, "but $-!$ You can't help yourselves now. It's what you're for. It's what Winkles is for. It's all right." 4 Even Winkles, the primarily foppish doctor to Redwood's son, Teddy, becomes freely involved with the revolutionary food. The doctor's choice is motivated by purely financial reasons. He sees the food in terms of the cash return he can realize if he allies himself with the creators. This is clear when he remarks:

These accidents,... are nothing, Nothing. The discovery is everything. Properly developed, sultably handled, sanely controlled, we have--we have something very portentlous indeed in this food of ours... We must keep our eye on it... We mustn't let it out of control again, and--we mustn't let it rest. 5

His interest is money and as such quite different from the "vision" one sees twinkling in Redwood's eye.

The vision that Wells refers to and develops throughout the nove1 is the vision of "mysterious half-shapen promises for the mighty future of man." Wells tells us this very early in the story. Later, Cossar refers to it when he reassures Redwood with, "Thank God he has a use for you!" Throughout, the food and growth itself become a metaphor for this vision, which is summarized in the final speech of Cossar's

${ }^{4} \mathrm{H} . \mathrm{G}$. Wells, The Food of the Gods (New York: Berkley Highland Books, 1967), pp. 100-101.

${ }^{5}$ Ibid., p. 90. 
son of the eve of the impending battle between the "1ittle folks" and the Giants. He explains:

It is the step we fight for and not ourselves... We are here, Brothers, to what end? To serve the spirit and the purpose that has been breathed into our lives. We fight not for ourselves--for we are but the momentary hands and eyes of the 1ife of the world. So you, Father Redwood taught us. Through us and through the little folk the Spirit looks and learns... We fight not for ourselves but for growth, growth that goes on for ever. To-morrow, whether we live or die, growth will conquer through us. That is the law of the spirit for evermore. To grow according to the will of God. ${ }^{6}$

It is part of Wells' vision that his "Life of the World" was both ordered and directed. The ordering was clearly perceivable to him from his studies in the sciences and the direction came from the belief that evolution resulted from the life force's attempt to understand itself. In later works this perception was augmented by the concept of the Superman, which Wells called the "Samurai." Like the Giants, the Samurai were one step further in the evolutionary process that is the Life of the World. That step normally would take millions of years, if man survived that long. When the Superman arrived, the millenium would exist on earth and the destiny of the Life and of man would be fulfilled. Destiny here is not providence nor a fatalist belief. Destiny does not robmankind of its freedom of choice. Bensington, Redwood, Cossar, and the Giants themselves, freely choose to align themselves with the Life of the World. In doing so, they are enlightened to the future of mankind, they become a part of something bigger than mere involvement in dead and dying social institutions. Those people like Caterham and the Skinners who are not 
enlightened do not know the Life and its importance, are unaware that a choice even exists. There is no alternative to the life and society in which they Iive. Like Blake's Spirit of Los, the Life of the World is the creative impulse which will raise man to the limits of his capabilities. Indeed, he may find that no limits exist. Evolution in Wells' sense is, then, like the recreation of the unfallen state we saw earlier with Blake.

There is, however, the chance that the Life may fail, that the drive for creation and for perfection may be thwarted. Uncontrolled society can reverse the positive forward movement. This is precisely the threat of the "little folks" led by Caterham. The power of popular opinion in opposition to the food forces Redwood and the others to increase production to insure the survival of the food. In an earlier work, The Time Machine, we see an instance in which the choice made by Redwood has not been made. Class conflicts resulted in the deevolution of the "haves" into docile cattle-like Elol and the "havenots" into cannibalistic Morlocks. This almost happens again in The Food of the Gods as Caterham attempts to halt the evolutionary process and maintain the status quo. Cossar spoke of this danger when he warned, "They're going to try and stop it, but they're too late." Yet the implication remains that, had Caterham been elected to power soon enough he could have suppressed the food and stopped the Giants. For this reason alone, the ever practical Cossar continually exhorts Redwood to "make as much as you can and as soon as you can. Spread it about." In doing so, he insures their success. 
G. B. Shaw

Similar to Wells' belief in the Life of the World is George Bernard Shaw's belief in what he calls "The Life Force" and "Creative Evolution." However, Shaw was interested in slightly different aspects of his theory than We1ls. As a dramatist, Shaw was primarily interested in dramatic conflict and as he perceived the Life Force, an abundant supply of conflict could be found within the theory. Where Wells dealt straightforwardly with conflict that arises from established society colliding with the onward drive of evolution, Shaw added the complication of seeing the drive of the Life Force as the source of conflict between the sexes. In the dedication of the play Man and Superman, Shaw lamented that, "we have no modern English plays in which the natural attraction of the sexes for one another is made the mainspring of the action."1 Desiring to amend this situation, he wrote the play Man and Superman: A Comedy and a Philosophy. In terms of the Hero of Choice, it is a complicated play. The three acts which deal with the conflict between Tanner and Anne represent a choice different from the action and choice which appears in the Don Juan act. In Wells, one has the impression of a single propelling force. This is not so. with Shaw. His Life Force has two aspects which together make up the evolutionary process. These two apsects are the biological and the intellectual. Since they are equated, in general, with the female and the male respectively, they are in a constant state of

${ }^{1}$ George Bernard Shaw, Man and Superman in Four Plays by Bernard

Shaw (New York: Washington Square Press, 1972), p. 263. 
overt and covert war. In order to sort out the problem of the Hero In Superman, the philosophy of Shaw proposed must first be sorted out.

Shaw, himself, recognized that there was a problem with the philosophy of Man and Superman. In a preface to the later play, Back to Methuselah, he admitted that Man and Superman had become a tale of a "husband huntress," and that because of this, in the earlier play the "evolutionary doctrine" was obscured. Consequently, in "In the Beginning" Shaw returned to the Garden of Eden to explain what his audience had missed in Superman. There we find Adam and Eve created not by God but by Lilith, the first human being. Lilith was convinced by the serpent that she must reproduce herself in order to overcome death. The serpent relates the story to Eve:

She [Lilith] saw death as you saw.it when the fawn fe11; and she knew then that she must find out how to renew herself and cast the skin like me. She had a mighty will: she strove and strove and willed and willed for more moons than there are leaves on all the trees of the garden. 2

And so she changed her skin and there were two new beings in the garden, Adam and Eve. The serpent then convinced Eve that she too must bear children in order to insure that the species would survive.

The garden was the beginning and the essence of what Shaw was trying to explain in Man and Superman. There is where it all began and what goes on today is traceble back. Shaw believed that English society had become largely bourgeois. Women no longer suffer quietly the wrongs done

2 George Bearnard Shaw, Back.to Methuselah (New York: Oxford University Press, 1947), p. 7. 
to them, but take recourse and revenge through law and social institutions. This is not at all surprising, for as Shaw shows in the garden it is Eve who is the aggressor:

As a result, man is no longer, like Don Juan, victor in the duel of sex. Whether he has ever really been may be doubted: at all events the enormous superiority of Woman's natural position in this matter is telling with greater and greater force. 3

So concludes Shaw. He says "That men should put nourishment first, and women, children first is, broadly speaking, the law of Nature and not the dictate of personal ambition." 4

Ann Whitefield is one such aggressive woman. She is the huntress Shaw was speaking about. She represents the biological aspect of the Life Force, and in order to achieve her goal, she is after Tanner. He is the target and her prey from the moment the play opens. She has manipulated her father into making Tanner joint guardian with Ramsden. The ploy serves to keep Tanner well within range of Ann's guns. But Ann, like Eve, follows Nature's purpose, and doing so, is driven by the force of Nature to capture a husband and have children. Here is the essential difference between Shaw and We1ls.

With Wells, the individual chooses to act in accordance with the evolutionary process in opposition to the status quo. Shaw presents the reverse. To Shaw, the character of Ann has no choice. She is determined to act as an agent of the Life Force by the "Law of Nature." The Life

\footnotetext{
${ }^{3}$ Shaw, Four plays, p. 267.

${ }^{4}$ Shaw, Four Plays, p. 269
} 
Force in Shavian terms comes to be a kind of cosmic status quo and the Hero who chooses must choose to act in opposition to that which Ann represents. Consequent1y, Tanner is very upset with his appointment as joint guardian.

At this point, Tanner is entirely unaware of Ann's intention to wed him. He is aware of the nature of women and this is the basis of his objection. He does not want to be held responsible in any way for her actions. As he explains to Ramsden:

She' 11 commit every crime a respectable woman can; and she' 11 justify everyone of them by saying that it was the wish of her guardians. She'11 put everything on us; and we shall have no more control over her than a couple of mice over a cat. 5

Part of Tanner's objection comes from the fact that he is aware of the reality of the situation that exists between men and women. He has glimpsed the vision and perceives himself to be an artist, and the artist is a threat to the designs of the woman, for he spends most of his time and energy chasing after "secondary ideals" and not in seeking nourishment. In addition, Shaw says:

The artist is either a poet or a scallawag: as poet, he cannot see, as the prosaic man does, that chivalry is at the bottom only romantic suicide; as scallawag, he cannot see that it does not pay to sponge
and beg and lie and brag and neglect his person. 6

But if he was not that way, slightly romantic and greatly stubborn, he would never perform his function and that is, "to carry on the work

${ }^{5}$ Four Plays, p. 295.

6 Ibid. p. 269. 
of building up an intellectual consciousness of her (Nature's) own Instinctive purpose." 7

This concept of art and the artist is as crucial to Shaw's philosophy as the part played by procreation and women. The aspect of the Life Force represented by women is without direction, mindless, a generating and regenerating drive towards an unknown biological end. Without any direction or knowable goal, the evolutionary process has an extremely important role for the artist. For through him and his Imagination, intellectual direction is given to the Life Force.

This is what Shaw means by "intellectual consciousness." In this sense then, both the artist and the woman are aspects of the Life Force, the one to create intellectually, the other biologically. "Accordingly we observe in the man of genius (artist) all the unscrupulousness and all the 'self-sacrifice' (the two things are the same) of woman." 8 Tanner warns Octavius of what happens when a meeting between the two takes place:

The true artist will let his wife starve, his children go barefoot, his mother drudge for his living at seventy, sooner than work at anything but his art. To women he is half vivisector, half vampire. He gets into intimate relations with them to study them, to strip the mask of convention from them, to suprise their inmost secrets, knowing that they have the power to rouse his deepest creative energies, to rescue him from his cold reason, to make him see visions and dream dreams, to inspire him, as he calls it. He persuades women that they may do this for their own purpose whilst he really means to do it for his. He steals the mother's milk. and blackens it to make printers ink to scoff at her and glorify ideal women with. He pretends to spare her 
the pangs of child-bearing so that he may have for himself the tenderness and fostering that belong of right to her children. Since marriage began, the great artist has been known as a bad husband. But he is worse; he is a child-robber, a bloodsucker, a hypocrite and a cheat. Perish the race and wither a thousand women if only the sacrifice of them enable him to act Hamlet better, to paint a finer picture, to write a deeper poem, a greater play, a profounder philosophy! For mark you, Tavy, the artist's work is to show us as we really are. Our minds are nothing but this knowledge of ourselves; and he who adds a jot to such knowledge creates new mind as surely as any woman creates new men. 9

When a woman meets such a man, there results a clash of wills that is often tragic. For, each is equal to the other in purpose. This conflict has even greater consequences, for the woman is fighting for the assurance of the survival of the race and the man for the intellectual consciousness of what the Life Force is all about.

In Superman, Tanner chooses to act as an artist. He understands the relationship between men and women. Octavius acts as a man, trying to secure Ann as a wife, doing what men have convinced themselves should be done in a situation they really have no control over. But at the end of the play it is Tanner who is to be wed, and Tavy who discovers a purpose of his own. He and Tanner switch their roles in much the same manner that Richard Dudgeon and Anthony Anderson do in The Devil's Disciple. Tanner, the political and social revolutionist, is used by Shaw to propose his doctrine of Creative Evolution and enhance the tension of the play by making him both the Hero of Choice and the pursued. In doing so, the irony of his marriage to Ann is increased. Tavy, we are told 
from the beginning, is an artist and when Ann tells him that she is going to marry Tanner, she explains that their marriage cannot be. She and Tavy would be at cross purposes to the plan of the Life Force. 10 Therefore, he must let her go and she must not take him. By condemning him to be a bachelor with an imperative must, she also identifies him with Don Juan, who is condemned by society to he11. Consequently, within the span of the play, Octavius becomes aware of his role as part of the Life Force and Tanner, the Hero of Choice, who ultimately fails, fulfills his function as husband to Ann.

The real problem with the identity of these two characters is the fact that Man and Superman was written immediately following Shaw's own marriage. He is sympathetic to Tanner in that he is in the same position. Tanner believes his marriage will make him "wretched" and looks upon it as defeat. Shaw can't leave it end on such a pessimistic note, so he allows Ann and all women to have the ability to "enrapture" their men. What this is, is the communication of the joy of her fulfillment of the purpose of the Life Force to him. Consequently, the "enrapture" is the positive element necessary to turn the apparent defeat of the hero into some sort of success. So, Tanner reluctantly resigns himself to the role he is forced to play in the greater purpose of the Life Force. His belief in his future wretchedness stems from the fact that he has glimpsed the truth and desired to be greater than he is, but he is not the Superman, only a man.

${ }^{10}$ Four Plays, p. 425. 
Tanner's dream of Don Juan in the third act, shows us another Hero of Choice. But more than that, it is intended to show us and Tanner that his Choice to act in opposition to the woman, Ann, is wasted effort. The act of Tanner is almost a wrong act.

Don Juan is the personification of Tanner's revolutionary beliefs, but the choice he makes is opposite to what Tanner has chosen. Juan has been condemned to Hell for his anti-social behavior. There he discovers that:

Hell is the home of the unreal and the seekers for happiness. It is the only refuge from Heaven... the home of the masters of reality, and from earth, which is the home of the slaves of reality... Here you call your appearance beauty, your emotions, love, your sentiments heroism, your aspirations virtue, just as you did on earth; but here there are no hard facts to contradict you, no ironic contrast of your needs with your pretentions, no human comedy, nothing but a perpetual romance, a universal melodrama. 11

We have been misled by the "Fathers of the Church" to believe Hell a place of torment and pain, but it is just as earth, a world of sense, steeped in the melodramatic nonsense which keeps us from discovering the truth; that nonsense that has told us that life is beauty and happiness, art good, and chastity the best of virtues: It is a real Hell for Don Juan because he has discovered the truth. The choice he had made while alive, just like Tanner's, to oppose the Life Force was based upon only limited knowledge. Now, in Hell, he discovers that the proper choice is that of Redwood and Cossar to support the Force.

${ }^{11}$ Four P1ays, pp. $377-375$. 
Consequently, when Juan discovers that he is free to go to Heaven, that is where he goes. For, in Heaven, "you live and work instead of playing and pretending. You face things as they are; you escape nothing but glamor; and your steadfastness and your peril are your glory."12 He determines that: "Thither I shall go presently, because there I hope to escape at last from lies and from tedious, vulgar pursuit of happiness, to spend my eons in contemplation."13

To the disgust of his listeners, he explains why it is contemplation that he desires. Life is "the force that ever strives to attain greater power of contemplating itself."14 Juan can conceive of no greater joy than to assist the Life Force in its upward climb:

Think of how it wastes and scatters itself, how it raises up obstacles to itself and destroys itself in its ignorance and blindness. It needs a brain, this irresistable force, lest in its ignorance it should resist itself. What a piece of work is man! says the poet. Yes: but what a blunderer! Here is the highest miracle of organization yet obtained by life, the most intensely alive thing that exists, the most conscious of all the organisms; and yet, how wretched are his brains. Stupidity made sordid and cruel by the realities learn't from toil and poverty: imagination resolved to starve sooner than face these realities, piling up illusions to hide them, and callling itself cleverness, genius! And each accusing the other of its own defect: Stupidity accusing Imagination of folly, and Imagination accusing Stupidity of ignorance: whereas, alas! Stupidity has all the knowledge, and Imagination all the Intelligence. 15

12 Four P1ays, p. 378.

${ }^{13}$ Ibid.

${ }^{14}$ Ibid.

${ }^{15}$ Ibid., p. 379 
He concludes by saying, that Creative Evolution attempts "to build up that raw force into higher and higher individuals, the ideal individual being ominpotent, omniscient, infallible, and withal completely, undilutedly self-conscious" 16 and that the focus of this is the brain "an organ, by which it can attain not only self-consciousness but self-understanding." 17

Juan's choice is to join forces with Creative Evolution. In doing so he seeks to lend direction to its otherwise blind and ingnorant onward movement. His choice is to become the artist. Not the artist in its limited sense as Tanner perceives it, but in its reality. Juan has an advantage over Tanner. Tanner is still one of the "slaves of reality" and as such he is Involved in the "dual of the sexes." He can see only the plight of men at the mercy of women and chooses to oppose Ann. But Juan is no longer a slave of reality. He goes to Heaven to become a master of reality.

${ }^{16}$ Four P1ays, p. 386.

${ }^{17}$ Ibid., p. 387. 
CHAPTER VI

\section{FANTASY}

The Heroes of Choice we have seen to this point in the works of Wells and Shaw could be described as revolutionaries. However, the term revolutionary does not adequately convey the true meaning of this hero's act. One would hardly describe Hardy's Jude as a revolutionary, for as we saw earlier the one choice he makes, to seek success through education is quite in line with society's mores. The additional choice, made jointly with Sue, is less the act of the revolutionary than it is simply rebellious. Their decision not to marry is once again the selective act of rebellion to a specific aspect of society or social institutions. As social rebellion is the basis of the revolutionary, so, to a lesser degree, is such rebellion essential to the rebel. From the position of the established order the activity of both is determined to be negative. But the difference between the two is defined as a matter of the degree of the negative involved. Hence the distinction made earlier in the introduction between the revolutionary and the rebel. Where the revolutionary attempts to overthrow and destroy the established order, the Hero of Choice is more selective. Jude questions the institution of marriage and marriage laws and Tanner, although a self-expressed revolutionary, really only confronts society on the issue of marriage and sex. Redwood is equally selective. He perceives society as a river dammed, a stagnant pond, unable to move from its prison banks to its destination, 
the sea. His food bursts the dam and allows the Society of Man to continue on its destined course.

In works of modern fantasy this selectivity is manifested in many ways, some of which deal with the total destruction of a specific object. For example, J. R. R. Tolkien's Frodo must destroy the Ring while Lewis' Ransom must destroy the research center N.I.C.E. The negative act of the Hero of Choice when portrayed in works of fantasy has an added element of creation. It is not merely "un-creation" but what I choose to call negative-creation. The negative act that the hero accomplishes can not be divorced from the creative results which accompany it. His creativity arises from that something which is destroyed. Since he is not God he cannot create from nothing. He is human and still has all the normal human failings. Instead of God-like creation, the Hero of Choice's act of negative-creation sets free something which we already possess. Frodo's quest not only helps destroy Sauron, but it also sets free the flow of history. Sauron threatens not only the total enslavement of the world but the seizure of time itself. This is very similar to the perception of Wells' Redwood in The Food of the Gods. In each case the creation of the hero sets the clock in motion once again.

To this point I have used the term fantasy several times, and since the chapter which follows will concern itself with two such works, it is appropriate here to explain what I consider to be included by that term. Over the years fantasy has meant everything from a power of creativity to a hallucination. But at the present time it should be considered as applying to a particular literary mode as specific as any other. Fantasy is differentiated from romance on the basis of the two types of heroes discussed thus far. As romance developed to include 
the addition of H. G. Wells' Science Romance, and Charles William's Theological Romance, as well as various forms of stories based upon psychic experience and the older form of the Gothic Romance; the new form, fantasy, also appeared. Fantasy incorporated the Hero of Choice as one of its primary characteristics. Fantasy has come to mean: a form of romance which contains the supernatural. In addition, that element of the supernatural is presented in such a manner as to be credible both internally to the characters and externally to the readers. When an author succeeds in establishing this credibility, he achieves the final goal of fantasy, that is: the creation of myth.

\section{A Form of Romance}

Describing a fantasy as a form of romance necessitates that the fantasy contain the recognizable elements of the romance. Some of these are: the journey-quest, the episodic nature of the narrative, and the lack of verisimilitude in the sense of being true to our reality. By extension a fantasy is a fiction. Consequently, such works as The Hermetic and Alchemical Writings of Peraclesus and Occult Philosophy or Magic by Cornelius Agrippa, which deal with magic and the supernatural are not within the bounds of this definition. These works are, in fact, treatises which attempt to convince us that magic is real and proceed to develop a curriculum by which one may attain the position of a magician. A work such as Conan Doyle wrote on the fhenomenon or hoax (depending on one's point of view) of the Cottingly fairies is fascinating in implication and erudition, yet 
its purpose is to "produce absolute credence in the reader."I It is obvious that none of these works is romance. If Doyle had chosen to rewrite The Coming of the Fairies in the form of a romance, dealing with the exploits of the children in a fictive manner, he would have met the first requirement of fantasy.

\section{Adventures of the Hero of Choice}

As has already been discussed the traditional hero of romance is the Hero of Success. He engages in a lengthy journey to obtain an object or goal with the aid of certain sympathetic helpers. Along the way he encounters strange creatures and stranger situations which enhance the adventure of the story. Only after many of these encounters and trials have been overcome does he achieve his goal. This is true of fantasy as well, except that in fantasy the hero is not culturally determined, but acts as a free agent. The hero of fantasy makes a choice; he must make a choice, and that choice must be freely and consciously arrived at. The Hero of Choice must not be motivated by the social context of his position in the society he represents. In addition the choice must be made between good and evil, and this leads then to the adventures and the quest.

W. H. Auden addresses hemself to the question of heroes when he says:

In our subjectives experience. . . what we ought to become is usually dependent upon what we are; it is idle and cowardly

${ }^{1}$ C. N. Manlove, Modern Fantasy: Five Studies (Cambridge: University Press, 1975), p. 2 . 
of me if I fail to make the fullest use of any talent with which I have been endowed, but presumptuous of me to attempt a task for which I lack the talent it requires. That is why, in the traditional quest story, the hero desires to undertake the quest and, even when to others he appears lacking in power, he is confident of success. 2

What this yields is two types of heroes or to use Auden's phrase, "two types of vocation." The one is the hero of talent (Success) in that he has the ability, power, or strength to perform the necessary task. The other is a hero of calling (Choice), in one respect like that of the religious "calling" of God, or as "when a man, by nature physically timid, is called to enter a burning building to rescue a child because there is no one else around to do it." 3 However, both types may become aware that a choice exists, then desire to make the choice. The hero of talent becomes the Hero of Choice only after he has chosen. When he does not choose, lets society determine him, he remains a Beowulf or Gawain. Likewise the hero of calling must choose.

\section{Contains the Supernatural}

The supernatural in fantasy may be monsters, magic, witches, or wizards, or almost anything that violates our objective reality. In violating our objective reality the supernatural becomes the impossible. When that element becomes possible or even probable following from some hypothesis, as in science fiction, it becomes something other than fantasy. Science fiction and utopian literature are the primary examples

${ }^{2}$ W. H. Auden, "The Quest Hero" in Tolkien and the Critics, eds. Neil D. Isaacs and Rose A. Zimbardo (Notre Dame: University of Notre Dame Press, 1968), p. 54.

3 Auden "The Quest Hero", p. 54. 
of this. Since dreams and nightmares are part of our objective reality works that utilize the dream-frame stories are excluded. The most wellknown of these are the Alice books of Lewis Carroll. Similarly such works as Bulgakov's The Master and Margarita which have been labelled fantasies by structuralists due to the plotless nature of the narrative and emphasis on the coincidental are not fantasies because their aim is to present a new perception of reality.

An additional aspect of the supernatural is the integrity both internal and external with which these supernatural elements must be presented. An author achieves internal integrity primarily by not satirizing the supernatural. Magic is one thing that must not be made fun of. If there is any satire at all in the work it must not satarize magic. ${ }^{4}$ When an amulet or enchanted sword appears in the story, it is a serious matter and the hero who bears them is increased in power and strength against his foes in proportion to those gifts. Likewise when the story contains a wizard or magician, he may be hated as Wormtongue hates Gandalf in The Lord of the Rings, but he is a personage who commands respect, regardless of what may be said behind his back. The supernatural equals power in the world of fantasy and everyone in that world believes in it. The characters are not surprised or horrified when it is used for or against them. In Lord Dunsany's The Charwoman's Shadow, the magician tells Ramon Alonzo that the price of the education he seeks is the loss of his shadow. Ramon is neither surprised nor unbelieving that such a price may be exacted, he is merely reluctant to

\footnotetext{
${ }^{4}$ J. R. R. Tolkien, Tree and Leaf (Boston: Houghton Mifflin Co.,
} 1969), 0. 10 . 
give up his shadow. Nor is he surprised later when he discovers that the magician sends the shadows he had bargained for to the corners of the universe to gain knowledge for him. Nowhere does Dunsany make fun of the magician's powers. In fantasy the supernatural is a serious matter.

When a fantasy succeeds in accomplishing this internal consistency, it is well on the road to producing the external integrity required by the reader. Tolkien calls this external integrity "Secondary Belief," 5 and it is accomplished by inner consistency. Each element, whether supernatural or not, must be consistent with every other element. When this occurs, an author can say, "green sun" and it will be believable in this "Secondary" sense. It is the reader who perceives this consistency and exhibits secondary belief while reading. However, if the supernatural may be interpreted symbolically or as a disquised element of reality, external integrity is violated and secondary belief fails. ${ }^{6}$ The animals that speak and interact in Aesop's beast fables are invested with the supernatural, but they are also representative of specific human characteristics and are intended to be read as such. Beast Fables are not fantasies. When one begins a consideration of the supernatural, one must eventually come to myth. This is especially true in the case of fantasy since the ultimate goal of secondary belief is to create new myth. This new myth is distinguished from the older myths of classical Greece, of the Romans, the Norse, and of Christianity, in that rather than having theology or metaphysics at its basis, fantasy has naturalism. There

${ }^{5}$ Tree and Leaf, p. 46-55.

6.Modern Fantasy, p. 5. 
are two movements in the creation of myths. The first is a movement from Gods down to the level of Man, and the second is a movement from nature up to the level of Man. The former is classical, the latter is romantic, and It is unfortunate to have to use the terms "up" and "down". The former implies a higher origin, but both attempt to explain the unexplainable, give order to an otherwise chaotic existence, and discover truth. This is all myth does, and neither movement is exclusive of or better than the other.

Two passages will perhaps illustrate this difference between the two movements, one from Tolkien and one from the Bible. Both deal with a supernatural incident; both utilize a staff as the instrument of power, and both situations are an attempt to persuade a king to a different point of view.

The first, from Tolkien's Lord of the Rings, occurs when Gandalf and company enter the hall of King Theoden to persuade him to give up the evil council of Wormtongue and become involved in the affairs of the world. A position of neutrality is no longer reasonable, for the evil of Sauron is growing and does not recognize neutrality. At the critical point of the debate, Gandalf

raised his staff. Then was a roll of thunder. The sunlight was blotted out from the eastern windows; the whole ha11 became suddenly dark as night. The fire faded to sullen embers. Only Gandalf could be seen, standing white and tall before the blackened hearth. 7

7. R. R. Tolkien, The Lord of the Rings (Boston: Houghton Mifflin Co., 1965), Vol. II, p. 118-19. 
Consistent throughout the trilogy is a total lack of religious cult, ceremony or ritual. ${ }^{8}$ Here, too, there is no prayer to a higher being. Gandalf's power to show Theoden the encroaching darkness from the east, comes not from above but from within himself.

The situation in Exodus $(7: 8-10)$ is very different. Moses and Aaron wish to go before the Pharaoh in order to convince him to free the chosen people. But their power is not from within themselves, instead:

the Lord spake unto Moses and unto Aaron saying, When Pharaoh shall speak unto you saying, Shew a miracle: then thou shalt say unto Aaron, take thy rod, and cast it before Pharaoh, and it shall become a serpent.

And Moses and Aaron went in unto Pharaoh, and they did as the Lord commanded: and Aaron cast down his rod before his servants and it became a serpent.

Moses and Aaron have no real power at all. They are only instruments through which God works. The only power they have is to communicate with God and be used by him. An interesting point of contrast is that of the two episodes only Gandalf's succeeds. The Pharaoh is unconvinced and must experience the plagues before he changes his mind. of these two movements the first, that from nature to man, is the one that fantasy is concerned with. When a work would otherwise meet a11 the requirements of fantasy but explains the supernatural in terms of the work of the Hand of God, it ceases to be fantasy. This is the case in many of the works of Charles Williams, which are works of theological romance rather than fantasy.

${ }^{8}$ Auden, "The Quest Hero," p. 53. 
CHAPTER VII

TOLKIEN AND LEWIS

J. R. R. Tolkien was aware of the importance of the Hero of Choice in fantasy. In The Lord of the Rings his hero is Frodo. C. N. Manlove said of the story and its hero: "At the center of his epic Tolkien has set out to place an ethic of heroic endeavour: The Ring-bearer against the whole might of Sauron."1 Manlove misinterprets certain key passages which cause him to conclude the work to be a failure in this respect, but that is beyond my scope here. Instead of arguing with him, I wish only to point out how important this concept of choice is to Tolkien and fantasy.- Tolkien laid great stress upon choice. It all began in the Shire. The Ring came to Frodo from Bilbo who thought it an attractive bauble, convenient to have in situations where one may wish to avoid certain people. But Gandalf revealed to Frodo that the ring was really the One Ring, the Ruling Ring, made by Sauron himself and invested with a11 the power of evil at his disposal. Engraved upon the Ring are two lines of a verse which reveal the evil nature of the Ring. Those lines are:

One Ring to rule them all, one Ring to find them, One Ring to bring them all and in the darkness bind them. ${ }^{2}$

1 Modern Fantasy, p. 174.

2 Lord of the Ring, Vol. I, p. 59. 
That Ring will corrupt and destroy anyone who wears it, but more important, wearing it will reveal its existence to its maker and the spies he has sent to find it. It is, in fact, so powerful that it may not be destroyed by conventional means and cannot be hidden. The Ring has a strange power of ideation of its own. It ever seeks to return to the one who made it. Hence the necessity that it be completely and forever destroyed. Hiding alone is not sufficient to keep it from Sauron. No one can insure that it will remain hidden.

Having been told this, Frodo's awareness of the problem is accomplished and the ensuing decision progresses over a number of pages. The decision consists of convincing himself of the validity of his choice. The salient points of which are:

'I am not made for perilous quests.'

'I cannot keep the Ring and stay here.'

'I should like to save the Shire, if I could--'

'I feel that as long as the Shire lies behind safe and comfortable I shall find wandering more bearable.'

'But this would mean exile, a flight from danger into danger, drawing it after me.'

'I suppose I must go alone. . . . 3

And the decision is thus made. For added emphasis Tolkien has Gandalf interrupt just before the end with, "And now. . The decision lies with you." 4 There is no one else who can make the choice for him. Frodo is

3 The Lord of the Ring, Vol. I, p. 70-72.

${ }^{4}$ Ibid., p. 71. 
like Auden's man facing the burning building. But Frodo has only decided to leave the Shire, to take the Ring into exile. At the Council held by Elrond in Rivendale, Frodo must choose again. At the Council Frodo decides that he will carry the Ring to Mordor to be destroyed in the fires from which it was made. At each successtve stage of the journey the choice must be made again. The decision and the journey have consequences that have to be dealt with and at each stage Frodo must choose to accept those consequences and continue or to turn back and quit. Such is the situation at the sundering of the Fellowship at the close of Book II. The decision must be made to continue south to Mordor or to turn west to Minas Tirith for a respite from the burden of responsibility that Frodo bears. To turn west means precious delay; to continue south means unknowable hardship. Consequent1y Aragorn tells Frodo:

I fear that the burden is laid on you. You are the bearer appointed by the Council. Your way you alone can choose. In this matter I cannot advise you. I am not Gandalf, and though I have tried to bear this part, I do not know what design or hope he had for this hour, if indeed he had any. Most likely it seems that if he were here now, the choice would still wait on you. Such is your fate. 5

Such is Aragorn's fate that he must decide as well. His decision, in the course of that passage, is to abide by the choice of Frodo. Tolkien's use of fate here should not be confused with some kind of providence or higher intervention in these affairs. It simply refers to the consequence of a chosen act. "Such is your fate." could easily be rewritten "such are the consequences of your choice."

$$
\text { 5ord of the Rings, Vo1. I, p. } 412 .
$$


Very shortly after the exchange between Frodo and Aragorn, Frodo finds himself alone atop Amon Hen. In his flight from Boromir who has tried to force Frodo to give up the Ring, Frodo has placed the Ring upon his finger. There on Amon Hen he confronts the ever searching power of Sauron. But, Frodo is no match for Sauron. To have Frodo subjected to the full power of Sauron, breaking his will--something Gandalf refused to do even to relieve him of the burden of the Ring-is unconscionable to the ethic of free choice Tolkien has worked so hard establishing. Left alone against Sauron, Frodo would surely break and become a slave to the power of the Dark Lord, just as so many others had. For this reason Frodo feels:

As a flash from some other point of power there came to his mind another thought: Take it off! Take it off! Fool, take it off! Take off the Ring! The two powers strove in him. For a moment, perfectly balanced between their piercing points, he writhed, tormented. Suddenly he was aware of himself again, Frodo, neither Voice nor the Eye! Free to choose, and with one remaining instant in which to do so. He took the Ring off his finger. 6

The "Voice" which cries "Fool, take it off!" is, of course, Gandalf's and not God or some providential being as Manlove misreads it. of all the characters in the Trilogy only Gandalf speaks to the hobbits in such a manner. By the rest, they are treated with deferential respect and occasionally open astonishment, wonder, or awe. However, the incident serves its purpose, Sauron is distracted in his attempt to dominate Frodo, and Frodo is left "free to choose."

${ }^{6}$ Lord of the Rings, Vol. I, p. 417. 
As his long journey draws to its end and the Ring comes closer to the living fires from which it was made, its power grows. Frodo staggers and crawls onward under its weight. So strong has it become, that standing at the "Cracks of Doom," he is unable to complete his task.

'I have come,' he said. 'But I do not choose now to do what I came to do. I will not do this deed. The Ring is mine!'7

But even in this, the moment of Frodo's failure, we are reminded of the importance of will. The denial of all the trust and hope that has been invested with him is still his right. All along the way he has chosen to carry out this trust. And now, at the last moment, he again makes a choice. Yet his failure is counter-balanced by the fact that the Ring is destroyed.

This may appear as contradictory to the concept of negative-creation, but it is not. Frodo had determined to be the Ring-Bearer, to carry it to Mount Doom. That which was to occur there was left to his descretion, to be faced by him at the required time. The destruction of the Ring would not have been possible without Frodo to carry it through all the perils and hardship to the place where it could be destroyed. Its destruction is a simple symbolic act which only helps insure the defeat of the Dark Lord by the free peoples of Middle Earth. As such the Ring is intertwined with all that Frodo has done. As a hobbit, he has chosen to act contrary to everything it is the nature of hobbits to be. Simply by beginning the quest and accepting the title Ring-Bearer, he has already

$$
\text { ' }{ }^{7} \text { Lord of the Rings, Vol. III, p. } 223 .
$$


performed the ultimate negative act.

The creative aspect is equally entangled, but with Tolkien's concept of time. According to Tolkien's myth, the destruction of the One Ring will also destroy the remaining three rings of power. Their destruction will mean the end of an entire period of history, the Third Age of Middle Earth. The next age, the Age of Men, will witness the passing of many beautiful things from the world. The elves, ents, and hobbits will disappear from Middle Earth, never to be seen again. But the birth of the new age, impossible under the iron hand of Sauron, means the beginning of new hope and a new period of history. Like the Phoenix, from the ashes of the Third Age, the Forth Age rises. There is a new world to be created and the energies of the people of Middle Earth are directed toward its creation. Political alliances are arranged and marriages are performed. Sam, the constant companion of Frodo, marries and fathers thirteen children.

Such creation also occurs in C. S. Lewis' That Hideous Strength, the final book in his space trilogy. As the research institute, N.I.C.E., is destroyed there is the same outburst of creativity. All the countryside becomes one outrageous copulating mass of living creatures. Even Ransom's last words to Jane Studdock are, "Have children."

Lewis' three books are interesting also in that as a single work, the development of the Hero of Choice is part of the development of the story. His works, intended as the discovery of myth, lead equally to the discovery of the Hero of Choice. In the first book, Out of the Silent Planet, one meets Ransom, a professor of linguistics. Ransom has the misfortune to meet Weston and Devine shortly after beginning a walking tour. Weston is a physicist who has discovered a method of interplanetary 
trave1, and Devine is an opportunist with a flair for making money. Before he can quite determine what these two are about, Ransom is drugged, kidnapped, and on his way to Mars. The reason for his abduction he discovers from an overheard conversation between his two abductors during the flight. Weston and Devine had kidnapped Ransom because on a previous visit the inhabitants of Mars had requested that a human be brought before the ruling being of the planet. Both Weston and Devine believe that this request has sinister intent, that the sorns have requested a human sacrifice.

A11 of Ransom's time on Mars is spent as a character in a romance.

- He had no choice in the matter of his abduction and consequently without a choice he cannot become a Hero of Choice. That which was offered to Frodo was not offered to Ransom. His adventures on Mars read as the adventures of any romance hero. This changes, though, during his last encounter.

As he comes before Oyarsa, the guiding spirit of the planet, he is finally offered the opportunity to determine the future course of his life. He may either stay on Mars or return with Weston and Devine to Earth. Ransom chooses to return. It is a seemingly simple choice to make, but it becomes complicated by the nature of the myth Lewis is trying to create. Both Tolkien and Lewis were concerned that their fantasies lead to the discovery of myth. Lewis' first story in his space trilogy is literally that, the discovery of myth by Ransom on Mars.

Lewis' myth is based upon a primarily Christian concept, but like Tolkien, Lewis is careful to keep God, the supreme being, at a safe distance from the activity of his creatures. Oyarsa is but one of many beings who like angels are free to travel wherever they wish across the 
vastness of space. Indeed, what we of Earth think space to be, i.e., a dead, empty void, is really teeming with life and vital energy. The misconceptions we live under are the cause of the being who is the spirit assigned to Earth. He is known in the Heavens as the Bent One, a Satan and fallen angel character. As Oyarsa explains to Ransom, this Bent one became perverted:

That was before any life came on your world. Those were the Bent Years of which we still speak in the heavens, when he was not yet bound to Thulcandra [Earth] but free like us. It was in his mind to spoil other worlds besides his own. He smote your moon with his left hand and with his right he brought the cold death on my Harandra before its time. . . We did not leave him so at large for long. There was great war, and we drove him back out of the heavens and bound him in the air of his own world as Maleldil taught us. 8

Since that time, this spirit has warped the growth and development of a11 life on this planet.

The choice thus offered to Ransom becomes one between living on Mars, a planet still in the un-fallen state, basking in the light of the true existence, and returning to Earth, the dark and silent planet. In addition Oyarsa tells Ransom "you are guilty of no evil, ...except a little fearfulness, for that, the journey you go on is your pain and perhaps your curse; for you must be either mad or brave before it is ended." 9 Ransom is charged with the responsibility, freely accepted, to watch Weston and Devine. He must see that they cause no more trouble

8 Out of the Silent Planet, p. 121.

${ }^{9}$ Ibid., p. 142. 
as agents of the Bent One. So resolved Ransom returns to Earth to fulfill his promise and his heroic quest to rid the Earth of this menace. From this point on he becomes the Hero of Choice and as such his adventures are recounted in the two remaining books.

As heroes, both Frodo and Ransom represent what Northrop Frye has called the "low-mimetic" hero. Their power as hero is aslimited as our own. In the face of such vast and seemingly impossible undertakings, they seem insignificant and their attempt hopeless. But the message that comes through all such works of fantasy is that hope does still exist. Aside from the discovery of myth, this is the single greatest quality that fantasy has to offer to the modern reader. "The Hobbits are rustic English people," Tolkien once said, "made sma11 in size because it reflects the generally small reach of their imagination-not the small reach of their courage or latent power." 10 Heroes such as these, even though limited, have an unlimited resevoir of courage that when the need arises, as it did in the First World War, may be tapped. Tolkien was readily aware of this from his own experience in that war. He said, "I've always been impressed that we are here, surviving, because of the indomitable courage of quite small people against impossible odds." 11

Against such impossible odds one alone can hope to do little. Frodo does not destroy the Ring and defeat Sauron. The event is accomplished

${ }^{10}$ Humphrey Carpenter, Tolkien: A Biography (Boston: Houghton Mifflin Co., 1977), p. 176.

11 Tolkien: A Biography, p. 176. 
through the combined efforts of all the peoples of Middle Earth. Similarly, Ransom can not defeat the "Bent One" by himself. The actual destruction of N.I.C.E. is carried out by the resurrected Merlin who uses his natural powers to unify nature against the totally unnatural institute. As Frodo is the Ring-Bearer in Tolkien's trilogy, Ransom becomes the Director in Lewis'. Neither has much possibility of success alone, and their efforts must be combined with others in order that the evil they confront may be destroyed. 


\section{CHAPTER VIII}

\section{CONCLUSION}

The purpose of this study was to examine two types of heroes that have appeared in literature over the years. Both are reflections of the periods and cultures which produced them. In the process of examining them, it was not my intention to recommend either one over the other or imply that the development of the Hero of Choice has replaced the older Hero of Success. No, both seem to occur with equal frequency in works today and both seem to experience equal popularity when they do appear. However, at this point it seems appropriate to draw some conclusions and even speculate about the value of these types on other than literary grounds.

The Hero of Success is representative of a cultural hero who reaffirms the values of his society. He is the product of an earlier stage in man's development when for survival a man had to lose himself in the law and social institutions. In doing so, he acted and more important succeeded without having to undergo moral or ethical choices because his society did that for him. Furthermore, the ultimate responsibility for his act resided not in himself but with his society. On the positive side, today he reassures the reader that, as a part of a given culture no matter how complicated or perverse, winning and success are still possible. It is possible as long as one follows the dictates of his society. The Hero of Success is, therefore, the essence of nationalism, the political term which describes the view of the world 
as divided into "us" and "them." He is the spirit of men in any age marching off to war to defend homeland and family from "them." But as Joseph Campbe11 explains,

The community today is the planet, not the bounded nation; hence the patterns of projected aggression which formerly served to co-ordinate the in-group now can only break it into factions. The national idea, with the flag as totem, is today an aggrandizer of the nursery ego, not the annihilator of an infantile situation. 1

The day of the Hero of Sucess has passed, it must pass. Today we are more aware of this fact than any other single age. Tolkien, at a dinner in his honor, made the toast,

I look East, West, North, South, and I do not see see Sauron; but I see that Saruman has many descendants. We Hobbits have against them no magic weapons. Yet, my gentle hobbits, I give you this toast: To the Hobbits. May they outlast the Sarumans and see spring again in the trees. ${ }^{2}$

The Sarumans of the world have converted the record of man over the last two-hundred years into that of one gigantic race to rape and exploit this once green planet. The race was periodically interrupted by warfare, at which time the methods of one nation were abhored by the others. Yet the rape continued, and Tolkien and Lewis could see that the race even benefited from these wars as business and industry made improvements on their methods. Now we are facing the reality of a world exhausted and about to be discarded in the best tradition of "no deposit, no return." We can no

$I_{\text {The Hero With a Thousand Faces, }}$ p. 388.

201kien; A Biography, p. 225-226. 
longer afford to listen to and place our trust in the ability of existing institutions to solve the problems that face us. To continue to revere a hero who relinquishes all responsibility to the society is a sure form of suicide. Man's dependence on society has produced progress, but it is progress negated by the fact that once again man is faced with the problem of mere survival, survival not only on the cultural level, but survival of the individual as well.

These are the same problems William Blake and the Victorians attempted to face more than a hundred years ago. The answer they proposed was acceptance of responsibility by the individual for the future direction of society. That individual became the Hero of Choice. He refuses to relinquish any responsibility to either his culture or his God. The act he performs is the act of modern redemption. Man is himself his own redeemer. If he fails, it is on his own head and not the fault of defective nature or fallen state. If he succeeds, the laurels belong to him. This is the message of Christ's death. As Campbe11 observes at the conclusion of his study, the modern hero knows that "It is not society that is to guide and save the creative hero, but precisely the reserve." ${ }^{3}$ The situation thus created is both optimistic and frightening. It is optimistic in that there are no limits placed upon the achievements of man. We even have the right to strive for the perfect state that was Blakes vision. It is frightening in that the burden is ours and, like Tolkien's Frodo and Lewis' Ransom, only we can bear. it.

3 Hero With a Thousand Faces, p. 391. 


\section{A SELECTED BIBLIOGRAPHY}

Altick, Richard D. 1973. 'Victorian People and Ideas, W. W. Norton \& Co...

Auden, W. H. 1968. "The Quest Hero," Tolkien and the Critics. Eds. Neil D. Issacs and Rose A. Zimbardo, Notre Dame: University of Notre Dame.

Bettelhiem, Bruno 1976. The Uses of Enchantment: The Meaning and Importance of Fairy Tales, New York: Alfred A. Knopr.

Bloom, Harold, Ed. 1970. Romanticism and Consciousness: Essays in Criticism, New York: W. W. Norton \& Co..

1971. The Visionary Company: A Reading or English Romantic Poetry, Ithica: Cornell University Press.

Campbe11, Joseph 1968. The Hero With a Thousand Faces, 2nd ed., New York: Princeton University Press.

Carlyle, Thomas 1907. Heroes and Hero Worship, and the Heroic in History, New York: Houghton Miff1in \& Co..

1973. "The Everlasting No," Victorian Prose and Poetry, Eds. Lional Trilling and Harold Bloom, New York: Oxford University Press.

Carpenter, Humphrey 1977. Tolkien: A Biography, Boston: Houghton Mifflin Co..

Carro1, Lewis 1976: The Complete Works of Lewis Carro11, New York: Vintage Books.

Carr, John Dickson 1975. The Life of Sir Arthur Conan Doyle: The Man Who was Sherlock Holmes, New York: Vintage Books.

Chretien de Troyes 1914. Arthurian Romances, Trans. W. W. Comfort, New York: Everyman's Library.

Dickens, Charles 1966. Bleak House, New York: W. W. Norton \& Co.. 1971. The Christmas Books, 2 vols., Ed. Michael Slater, Baltimore: Penguine Books.

1938. "Frauds on the Fairies," The Collected Papers, Bloomsbury: The Nonesuch Press. 
1966. Hard Times, New York: W. W. Norton \& Co..

Doyle, Arthur Conan 1967. The Annotated Sherlock Holmes, Ed. William

S. Baring-Gould, New York: Clarkson N. Potter.

1975. The Coming of the Fairies, New York: Samuel Weiser Inc..

Dunsany, Lord 1973. The Charwoman's Shadow, New York: Ballantine Books:

Frye, Northrop 1957. Anatomy of Criticism: Four Essays, Princeton:

Princeton University Press.

1976. The Secular Scripture: A Study of the Structure of

Romance, Cambridge: Harvard University Press.

1970. The Stubborn Structure: Essays on Criticism and Society,

Ithica: Corne11 University Press.

Forester, E. M. 1927. Aspects of the Nove1, New York: Harcourt, Brace \& World, Inc. .

Hardy, Thomas 1961. Jude the Obscure, New York: Signet Classics.

Homer, 1961. Iliad, Trans. Richard Lattimore, Chicago: Phoenix Books.

1932. The Odyssey of Homer, Trans. T. E. Shaw, New York: Oxford University Press.

Huxley, T. H. 1972. "Science and Culture," The Portable Victorian

Reader, Ed. Gordon S. Haight, New York: Viking Press.

Hynes, Samuel 1971. The Edwardian Turn of Mind, Princeton: Princeton University Press.

Kennedy, Charles W. Ed. 1940. Beowulf, New York: Oxford University Press.

Keynes, Geoffrey, Ed. 1974. Blake: The Complete Writings, New York: Oxford University Press.

Kotzin, M. C. 1972. Dickens and the Fairy Tale, Bowling Green: Bowling Green University Press.

Lewis, C. S. 1965. Out of the Silent Planet, New York: Macmillian Publishing Co..

1965. Perelandra, New York: Macmillian Publishing Co..

1965. That Hideous Strength, New York: Macmillian Publishing Co..

Macaulay, Thomas 1972. "The Six Points," The Portable Victorian Reader,

Ed. Gordon S. Haight, New York: Viking Press. 
Manlove, C. N. 1975. Modern Fantasy: Five Studies, Cambridge: Cambridge University Press.

Morris, William, 1975. The Well at the World's End, New York: Ballantine Books.

1973. The Glittering Plain, Hollywood: Newcastle Publishing Co.. 1973. Three Works by William Morris, New York: International Publishers.

Njal's Saga, 1974. Trans: Magnus Magnusson and Hermann Palsson, Baltimore: Penguin Books.

Noyes, Russe11, Ed. 1956. English Romantic Poetry and Prose, New York: Osford University Press.

Poe, Edgar Allen 1975. The Complete Tales and Poems of Edgar Allan Poe, New York: Vintage Books.

Robinson, R. N. Ed. 1957. The Works of Geoffrey Chaucer, 2nd ed., Boston: - Houghton Miffiln Co..

Rosenberg, Samue1, Ed. 1975. The Hound of the Baskervilles, by Arthur Conan Doyle, New York: Schocken Books.

Ruskin, John 1973. "The King of the Golden River," Beyond the Looking Glass, Ed. Jonathan Cott, New York: The Stonehill Publishing Co..

1973. "The Stones of Venice," Victorian Prose and Poetry, Ed. Llonel Trilling and Harold Bloom, New York: Oxford University Press.

Scott, Sir Walter 1879. "The Fortunes of Nige1," The Waverley Novels, Vol. IV, Philadelphia: J. B. Lippincott \& Co..

Shaw, George Bernard 1947. Back to Methuselah, New York: Oxford University Press.

1972. Four Plays by Bernard Shaw, New York: Washington Square Press.

The Song of Roland, 1973. Trans. Dorothy L. Sayers, Baltimore: Penguin Books.

Tolkien, J. R. R. 1965. The Lord of the Ring, 3 vols., Boston: Houghton Mifflin Co..

and E. V. Gordon, Eds. 1968. Sir Gawain and the Green Knight, 2nd ed., Norman Davis, New York: Oxford University Press. 
1967. Tree and Leaf, Boston: Houghton Mifflin Co..

Wells, H. G. 1967. A Modern Utopia, Lincoln: University of Nebraska Press. 1967. The Food of the Gods, New York: Berkley Highland Books. 1968. The Time Machine and The War of the Worlds, Greenwich, Conn.: Fawcett Publications.

Welsh, Alexander 1963. The Hero of the Waverley Novels, New Haven: Yale University Press.

Wilkie, Brian 1965. Romantic Poets and Epic Tradition, Madison: Univeristy of Wisconsin Press.

Wilsin, Angus 1970. The World of Charles Dickens, London: Secker and Warburg. 